\title{
Characterisation of Peptide5 Systemic Administration for Treating Traumatic Spinal Cord Injured Rats
}

Yilin Mao ${ }^{1}$, Tara Nguyen ${ }^{1}$, Ryan S Tonkin ${ }^{2}$, Justin G Lees ${ }^{2}$, Caitlyn Warren ${ }^{1}$, Simon J O'Carroll $^{3}$, Louise F B Nicholson ${ }^{3}$, Colin R Green ${ }^{4}$, Gila Moalem-Taylor ${ }^{2}$ and Catherine A Gorrie ${ }^{1^{*}}$

${ }^{1}$ Neural Injury Research Unit, School of Life Sciences, Faculty of Science, University of Technology Sydney, NSW, 2007, Australia

${ }^{2}$ Neuropathic Pain Research Group, Translational Neuroscience Facility, School of Medical Sciences, University of New South Wales, Sydney, NSW, 2052, Australia

${ }^{3}$ Department of Anatomy and Medical Imaging and the Centre for Brain Research, Faculty of Medical and Health Sciences, University of Auckland, Auckland 1142, New Zealand

${ }^{4}$ Department of Ophthalmology and the New Zealand National Eye Centre, Faculty of Medical and Health Sciences, University of Auckland, Auckland 1142, New Zealand

\section{*Correspondence:}

Dr. Catherine Gorrie

Neural Injury Research Unit

School of Life Sciences

Faculty of Science

University of Technology Sydney

P.O. Box 123, Broadway, NSW, 2007, Australia

E-mail: Catherine.Gorrie@uts.edu.au

Tel.: +61 295148298

Fax: +61 295148206

Key Words: Connexin43 mimetic peptides, connexins, spinal cord injury, systemic administration, tissue distribution, safety profile 


\section{Abstract}

Systemic administration of a Connexin43 mimetic peptide, Peptide5, has been shown to reduce secondary tissue damage and improve functional recovery after spinal cord injury (SCI). This study investigated safety measures and potential off-target effects of Peptide5 systemic administration. Rats were subjected to a mild contusion SCI using the New York University impactor. One cohort was injected intraperitoneally with a single dose of fluorescently-labelled Peptide5 and euthanised at 2 or 4 hours post-injury for peptide distribution analysis. A second cohort received intraperitoneal injections of Peptide5 or a scrambled peptide and were culled at 8 or 24 hours post-injury for analysis of connexin proteins and systemic cytokine profile. We found that Peptide5 did not cross the blood-spinal cord barrier in control animals, but reached the lesion area in the spinal cord-injured animals without entering non-injured tissue. There was no evidence that the systemic administration of Peptide5 modulates Connexin43 protein expression or hemichannel closure in the heart and lung tissue of SCI animals. The expression levels of other major connexin proteins including Connexin30 in astrocytes, Connexin36 in neurons and Connexin47 in oligodendrocytes were also unaltered by systemic delivery of Peptide 5 in either the injured or non-injured spinal cords. In addition, systemic delivery of Peptide5 had no significant effect on the plasma levels of cytokines, chemokines or growth factors. These data indicate that the systemic delivery of Peptide5 is unlikely to cause any off-target or adverse effects and may thus be a safe treatment option for traumatic SCI. 


\section{Introduction}

Peptide5 is a synthetic peptide that mimics a sequence in the extracellular loop 2 of Connexin43, a ubiquitously expressed gap junction protein found in the spinal cord (Lee et al. 2005; Stehberg et al. 2012; Theriault et al. 1997). Under pathological conditions, Connexin43 channel-mediated communication is involved in secondary cell death by propagating neurotoxic molecules, such as glutamate, nitric oxide, lactate, arachidonate, ammonia, reactive oxygen species and calcium waves from injured cells to adjacent healthy cells, a process known as the bystander effect (Lin et al. 1998; Scemes et al. 2000; Theriault et al. 1997). Additionally, the opening of uncoupled gap junction hemichannels alters the permeability of cell membranes to release neurotoxins to the extracellular space and can trigger calcium waves, which are then received by surrounding, previously uninjured cells (Davidson et al. 2015; Decrock et al. 2015; Orellana et al. 2011; Thompson et al. 2006; Ye et al. 2003). Peptide5 is able to regulate the communication of Connexin43 gap junctions and hemichannels independently, with short incubation times or low concentration restricting hemichannel opening without affecting the communication of existing gap junctions, whereas long incubation times or high concentration have been reported to prevent gap junction and hemichannel communication in experimental preclinical models (Abudara et al. 2014; Leybaert et al. 2003; O'Carroll et al. 2008; Yoon et al. 2010). Although the exact mechanisms of Peptide5 action remain to be fully elucidated, the most recent study revealed that Peptide5 acts on the extracellular loop 2 of Connexin43 (Kim et al. 2017). The authors also demonstrated that the Peptide5 sequence provides the most effective Connexin43 hemichannel blocking, with the SRPTEKT motif being central to the Peptide5 mechanism (Kim et al. 2017). 
Using an intrathecal catheter and an osmotic pump to deliver Peptide5 directly to the lesion area of the spinal cord in a rat contusion model, early studies demonstrated the neuroprotective efficacy of Peptide5 (O'Carroll et al. 2013). Local application of Peptide5 has also been explored in a number of pathological conditions in the nervous system including retinal ischaemia (Chen et al. 2015; Chen et al. 2014), cerebral ischaemia (Davidson et al. 2015; Davidson et al. 2013a; Davidson et al. 2013b), foetal ischaemia (Davidson et al. 2012a) and asphyxia (Davidson et al. 2014). Local administration may not be the most practical option for human spinal patients as, for example, the intrathecal delivery of Peptide5 may normally involve an invasive procedure immediately after a traumatic event, that may not be clinically prudent. Systemic administration is able to deliver proteins and mimetic peptides to the lesion area of the spinal cord even where the capillary bed has been compromised (Han et al. 2010), thus offering a practical therapeutic approach for people with spinal cord injury (SCI). A study of retinal ischemia-reperfusion with systemic Peptide5 delivery showed significant neuronal protection following peptide treatment (Danesh-Meyer et al., 2012) and a recent study by us has shown that systemic Peptide5 delivery is neuroprotective and improves functional recovery in a rat spinal cord contusion model (Mao et al. 2017). However, the safety profile of Peptide5 after systemic administration has not been experimentally examined.

Connexin43 protein is found in other tissues, including the heart (Gourdie et al. 1993; Gu et al. 2014; Van Kempen et al. 1991), brain (Deng et al. 2014; Nakase et al. 2004; Yamamoto et al. 1990), testis (Chevallier et al. 2013; Li et al. 2010; Steger et al. 1999), skin (Chang et al. 2015; Guo et al. 1992; Tada and Hashimoto 1997) and bone marrow (Dorshkind et al. 1993; Dürig et al. 2000; Zhang et al. 2006). Connexin43 mimetic peptides have been shown to regulate Connexin43 hemichannels and protect against ischaemic injury in the heart (Hawat 
et al. 2010; Hawat et al. 2012) and brain (Davidson et al. 2015; Davidson et al. 2013a; Davidson et al. 2013b). Following our demonstration that systemic delivery of Peptide5 is protective after SCI (Mao et al. 2017), we sought to assess whether Connexin43 hemichannels and/or gap junctions in tissues such as the heart are affected by this treatment.

In the spinal cord, there is a wide distribution of connexin gap junctions: astrocyte/astrocyte gap junctions contain Connexin30 and 43, neuron/neuron gap junctions contain Connexin36, and oligodendrocyte/astrocyte gap junctions containing Connexin29, 32 and 47, with the major heterotypic gap junction channels being composed of Connexin43-Connexin47 and Connexin30-Connexin32 protein combinations (Kleopa et al. 2004; Lee et al. 2005; Orthmann-Murphy et al. 2008; Rash et al. 2001; Rash et al. 1998; Tonkin et al. 2015). Although Connexin43 is the major connexin that has been reported to be altered following traumatic SCI, we also sought to evaluate whether that the expression of other connexins may be changed following blockade of Connexin 43 hemichannels by Peptide5 treatment.

In the current study, therefore, as an initial step towards translation to human SCI treatments, we examined safety aspects of Peptide5 systemic administration protocols including tissue distribution and systemic effects in our rat spinal cord injury model.

\section{Materials and Methods}

\section{Animals and animal care}

All experimental protocols and procedures used in the current study were approved by the Animal Care and Ethics Committee of University of Technology Sydney, in accordance with the guidelines of the National Health and Medical Research Council of Australia. There were 57 adult female Sprague-Dawley rats weighing 250-300 g used (Animal Resource Centre, 
Perth, Australia). All animals were maintained in standard cages with ad-lib water and food on a 12:12 hour light-dark cycle. Each animal's weight was checked at least twice a week.

The surgical procedures have been described previously in detail (Mao et al. 2017). Briefly, rats were anesthetised with $4 \%$ isoflurane in $1 \mathrm{~L} / \mathrm{min}$ oxygen and maintained at $2 \%$ isoflurane in $1 \mathrm{~L} / \mathrm{min}$ oxygen. Local anaesthetic (bupivacaine, $0.5 \%, 0.02 \mathrm{~mL}$ ) was injected at the surgical sites before an incision was made through skin and muscle layers over the dorsal midline. A T10 laminectomy was performed to expose the spinal cord and, in the 'SCI' groups $(\mathrm{n}=30)$, animals were subject to a mild contusion injury $(6.25 \mathrm{~mm}$ drop, $10 \mathrm{~g}$ weight) to the T10 spinal cord by using the New York University impactor. The 'sham' group $(\mathrm{n}=19)$ were subject to a T10 laminectomy only without SCI. The 'intact controls' (n $=8$ ) did not receive any surgical procedures. A summary of the animal cohorts and tissue samples obtained is provided in Table 1.

\section{Peptide treatment}

Peptide5 was designed to mimic a portion of the extracellular loop 2 of Connexin43 as described previously (O'Carroll et al. 2008). All peptides were solid phase synthesised, using chemistries on a Protein technologies, Symphony instrument, purified by high-performance liquid chromatography and the structure confirmed by mass spectrometry analysis. The dose of peptides used was chosen to match previous studies (Danesh-Meyer et al. 2012; Mao et al. 2017), in order to give an initial blood concentration of $100 \mu \mathrm{M}$. In the first cohort, a single dose of fluorescein isothiocyanate (FITC)-conjugated Peptide5 (sequence FITC-AVDCFLSRPTEKT, Auspep; $3.5 \mathrm{mg}$ in $0.5 \mathrm{ml}$ saline, equivalent to $10 \mathrm{mg} / \mathrm{kg}$ of Peptide5) was injected intraperitoneally to the SCI $(n=8)$ and intact control $(\mathrm{n}=8)$ rats immediately after surgery. In the second cohort, three doses of Peptide5 (sequence VDCFLSRPTEKT, Mimotopes) or scrambled peptide (SP) (sequence RFKPSLCTTDEV, Mimotopes) were 
delivered intraperitoneally to SCI $(n=22)$ and sham $(n=16)$ rats at 0 hours $(10 \mathrm{mg} / \mathrm{kg}$ in 0.5 $\mathrm{ml}$ saline), 2 hours $(5 \mathrm{mg} / \mathrm{kg}$ in $0.5 \mathrm{ml} \mathrm{saline})$, and 4 hours $(2.5 \mathrm{mg} / \mathrm{kg}$ in $0.5 \mathrm{ml} \mathrm{saline})$ following surgery. A single dose of vehicle control $(0.5 \mathrm{ml}$ saline $)$ was delivered intraperitoneally to sham animals $(\mathrm{n}=3)$.

\section{Post-operative care}

Post-operative animals were housed individually and given subcutaneous antibiotics (cephalothin sodium, $0.33 \mathrm{mg} / \mathrm{kg}$ ), analgesics (buprenorphine hydrochloride, $0.03 \mathrm{mg} / \mathrm{kg}$ ), and supplementary fluid (Hartman replacement solution, $3.8 \mathrm{ml}$ ) twice daily. Bladders were expressed manually twice daily.

\section{Euthanasia and tissue preparation}

The FITC-Peptide5 treated animals were euthanized with sodium pentobarbital $(100 \mathrm{mg} / \mathrm{kg}$, i.p.) and perfused intracardially with $200 \mathrm{ml}$ of heparinized saline at 2 hours $(\mathrm{n}=8)$ and 4 hours $(\mathrm{n}=8)$ after surgery. Approximately $10 \mathrm{~mm}$ of spinal cord centred at T10 and cervical enlargement as well as the major organs (brain, heart, lung, liver, spleen and kidney) were dissected for generating fresh frozen sections of $15 \mu \mathrm{m}$ onto Matsunami Platinum PLC-14 glass slides, using a cryostat (Leica, CM1950). Slides were rehydrated in water for 5 minutes and cover-slipped in fluorescent mounting medium (Dako).

The Peptide5 or SP treated animals were euthanized at 8 hours $(n=6)$ and 24 hours $(n=35)$ post-injury with sodium pentobarbital (100 mg/kg, i.p.). Cardiopuncture was then performed to collect $5 \mathrm{ml}$ of blood, and the plasma was extracted. Intracardial perfusion using heparinized saline and 4\% paraformaldehyde was performed. Approximately $20 \mathrm{~mm}$ of spinal cord centred at T10 were dissected and post-fixed in 4\% paraformaldehyde overnight and then stored in $30 \%$ sucrose, while hearts and lungs were removed and post-fixed in $10 \%$ formalin. Spinal cords were sectioned horizontally in a cryostat (Leica, CM1950). Sections were mounted in a series of 10 so that each section on a slide was at $150 \mu \mathrm{m}$ intervals. 
Approximately $5 \times 5 \times 3 \mathrm{~mm}^{3}$ of heart and lung specimens along with a representative lumbar spinal cord specimen (SCI with Peptide5 treatment at 8 hours post-injury) were processed for paraffin embedding and sections were cut at $5 \mu \mathrm{m}$. Mayer's haematoxylin and eosin (H\&E) staining was performed to assess tissue morphology.

\section{Immunohistochemistry}

Slides were rehydrated in xylene, decreasingly graded ethanol and phosphate buffered saline with Triton X-100 at $\mathrm{pH} 7.4$ (PBST), and incubated in 5\% normal goat serum (NGS) in PBST for 30 minutes. Primary antibodies were diluted in phosphate buffer with $2 \%$ NGS (PBG) and incubated overnight at $4{ }^{\circ} \mathrm{C}$. For the frozen sections of $\mathrm{T} 10$ spinal cord, primary antibodies used were rabbit anti-Connexin30 (1:250, Thermo Fisher), rabbit anti-Connexin36 (1:250, Thermo Fisher) and rabbit anti-Connexin47 (1:250, Thermo Fisher). For the paraffin sections of heart and lung, primary antibodies used were rabbit anti-Connexin43 (1:2000, Sigma-Aldrich) and rabbit-phosphorylated Connexin43-Ser368 (1:100, Santa Cruz). The phosphorylation of Connexin43 at Ser368 was used to recognise the closed state of Connexin43 hemichannels (Faigle et al. 2008; Lampe et al. 2000; O'Carroll et al. 2013). Slides were then washed in PBST and incubated with secondary antibodies: goat anti rabbit Alexa Fluor 488 (Connexin30, 36, 43 and 47; 1:200, Thermo Fisher) or goat anti-rabbit Alexa Fluor 568 (phosphorylated Connexin43; 1:200, Thermo Fisher) in PBG for 2 hours at room temperature. Primary antibodies were omitted from negative controls. All slides were cover-slipped in fluorescent mounting medium (Dako).

Representative paraffin sections of lumbar spinal cord were used to demonstrate the colocalisation of Connexin30 on astrocytes, Connexin36 on neurons, Connexin43 on astrocytes, and Connexin47 on oligodendrocytes. Slides were rehydrated in xylene, decreasingly graded ethanol and PBST. Heat-induced antigen retrieval was performed in citrate buffer $(10 \mathrm{mM}$ 
citric acid, $\mathrm{pH}$ 6.0) for 10 minutes in a pressure cooker for Connexin36/neuronal nuclei $(\mathrm{NeuN})$ staining. All sections were incubated in blocking agents for 30 minutes at room temperature (5\% NGS in PBST for Connexin30/glial fibrillary acidic protein (GFAP), Connexin43/GFAP and Connexin47/oligodendrocyte specific protein (OSP); 5\% skim milk for Connexin36/NeuN). The primary antibodies of rabbit anti-Connexin30 (1:250, Thermo Fisher), rabbit anti-Connexin36 (1:250, Thermo Fisher), rabbit anti-Connexin43 (1:2000, Sigma-Aldrich) or rabbit anti-Connexin47 (1:250, Thermo Fisher) were diluted in PBG and incubated overnight at $4{ }^{\circ} \mathrm{C}$. After washing in PBST three times, the slides were incubated with secondary goat anti-rabbit Alexa Fluor 488 or 568 antibody (1:200, Thermo Fisher) in PBG for 2 hours at room temperature. After washing in PBST five times, the slides were incubated with primary antibodies of rabbit anti-GFAP (1:1000, Dako), mouse anti-NeuN (1:1000, Millipore) or rabbit anti-OSP (1:3000, Abcam) in PBG overnight at $4{ }^{\circ} \mathrm{C}$. Following washing in PBST three times, the slides were incubated with the secondary goat anti-rabbit Alexa Fluor 488 or 568 antibody (1:200, Thermo Fisher) in PBG for 2 hours at room temperature. Slides were then washed with PBST and counterstained by Hoechst (1:5000, Thermo Fisher) for 10 minutes. Primary antibodies were omitted from negative controls. All slides were cover-slipped in fluorescent mounting medium (Dako).

\section{Imaging and quantification}

Imaging was conducted using an Olympus BX-51 light microscope with an Olympus U-RFL$\mathrm{T}$ fluorescence burner and appropriate filters. The black balance was adjusted using the negative control sections to normalise the mean grey scale value (GSV). Frozen spinal cord sections were aligned using the central canal as an anatomical landmark (midline) for immunohistochemistry analysis. Images were taken adjacent to the lesion and at both 3.5 and $7 \mathrm{~mm}$ distal to the lesion centre in both rostral and caudal directions. Image analysis was conducted using ImageJ software (National Institutes of Health, version 2X). Analysis of 
fluorescent immunohistochemistry was undertaken by measuring the total fluorescent intensity per image, mean GSV, in 20x images. High power images (100x) were taken for the double labelling of connexins and neural markers for visualising the distribution.

\section{Multiplex assay}

The plasma samples obtained from the 24-hour post-injury groups in Cohort II $(\mathrm{n}=8$ per group) were used for a multiplex assay to compare cytokines, chemokines and growth factors, as per manufacturer protocol (Bio-Rad, Bio-Plex Pro $^{\mathrm{TM}}$ Rat Cytokine 23-Plex Assay \#L8001V11S5). Briefly, plasma samples were diluted 1:4 and analysed following the manufacturer's instructions. The plates were pre-wetted with wash buffer (Bio-Rad) and loaded with $1 \times$ beads (Bio-Rad). The wells were rinsed by wash buffer (Bio-Rad) and then loaded with blank, standards, or samples for one-hour incubation. Following washing thre times, the detection antibodies were added for 30-minute incubation. The plates were washed and incubated in streptavidin-phycoerythrin for 10 minutes. After washing, the analytes were resuspended with assay buffer (Bio-Rad) for 30 seconds. The plates were read using the BioPlex reader (Bio-Rad), and results were converted to a $\mathrm{pg} / \mathrm{ml}$ concentration for all of the cytokines tested.

\section{Statistical analysis}

All data were expressed as mean \pm standard error of the mean (SEM). Unpaired t-test or oneway analysis of variance (ANOVA) with a Bonferroni post-hoc test was used to determine significant differences (PRISM, Version 6.0e, GraphPad). Differences were considered statistically significant at $p<0.05$. There were no significant differences between rostral and caudal measurements in mean GSV using the paired t-test and, therefore, the mean of rostral and caudal measurements for each sample was used for further analysis. 


\section{Results}

\section{Distribution of Peptide5 in vivo}

All surgical procedures and intraperitoneal injections of FITC-Peptide5 were conducted without incident. None of the rats showed any indication of complications from the SCI surgery or intraperitoneal injection. FITC-Peptide5 was visualised as green fluorescence in the frozen sections (Figure 1). There was no evidence of FITC-Peptide5 distribution in the cervical enlargement of spinal cord, brain, heart and liver tissue in either intact or SCI animals. FITC-Peptide5 was found in lung, spleen and kidney tissue in both control and SCI animals. FITC-Peptide5 presented in the T10 segment of spinal cord in the SCI rats, but not the intact controls.

\section{Connexin 43 protein in the heart tissue}

Due to the known abundance of Connexin 43 protein in the heart, additional investigation was undertaken using histology to confirm that there was no obvious alteration to the cardiac tissue or connexin43 levels as a result of peptide treatment. Heart sections stained by Mayer's H\&E showed the typical histological characteristics of cardiac muscle: single central nuclei, branching cell shape and muscle striation (Figure 2A). There were no observed differences in the histological morphology of heart tissue or the distribution of fluorescent staining between groups. Fluorescent immunohistochemistry staining demonstrated Connexin43 (Figure 2B) and phosphorylated Connexin43 at residue Ser368 (Figure 2C) proteins in the intercalated discs of heart tissue. The immunoreactivity levels of Connexin43 and phosphorylated Connexin 43 were measured by mean GSV for statistical analysis. There were no statistically significant differences in the immunohistochemistry labelling intensity of Connexin43 (36.06 \pm 9.32 ) between groups (Figure 2D). Similarly, no significant differences were found in the 
immunohistochemistry staining intensity of Connexin 43 phosphorylation at residue Ser368 $(18.86 \pm 3.73)$ between groups using one-way ANOVA analysis (Figure 2E).

\section{Connexin 43 protein in the lung tissue}

Due to the observation of FITC-Peptide5 in the lung sections additional investigation was undertaken using histology to confirm that there was no obvious alteration to the respiratory tissue or connexin43 levels as a result of peptide treatment. Lung sections stained by Mayer's H\&E staining showed histological characteristics typical of alveolar tissue: alveolar wall lined by type 1 pneumocytes (squamous epithelial cells) and type 2 pneumocytes (cuboidal epithelial cells), as well as alveolar macrophages found in the alveolar ducts and sacs (Figure 3A). In particular, the thickness of the alveolar wall and the number of erythrocytes were significantly increased in both spinal cord injured and sham rats compared with that expected in intact rats (Abdelaziz et al. 2016; Gauter-Fleckenstein et al. 2014; van den Brule et al. 2014). The alveolar wall was partially incomplete in all lung samples. However, there were no observed differences in the histological morphology of lung tissue between groups. Fluorescent immunohistochemistry indicated that there was no Connexin 43 protein located in lung tissue, so no further fluorescent immunohistochemistry staining of Connexin43 phosphorylation at residue Ser368 was conducted. The FITC-Peptide5 observed in the lungs is thought to be due to an artefact of cardiac perfusion.

\section{Major connexin proteins in the spinal cord tissue}

Immunohistochemical co-labelling for Connexin43 and GFAP, Connexin30 and GFAP, Connexin36 and NeuN, as well as Connexin47 and OSP was performed to determine the location of Connexin43, 30, 36 and 47 in the rat spinal cord (Figure 4). Connexin30 and 43 expression was found to be associated with astrocytes and their processes labelled for GFAP. Neuronal cells labelled by NeuN co-expressed Connexin36 protein in the spinal cord. Connexin47 expression was found to be associated with oligodendrocytes and their processes 
labelled by OSP. We previously demonstrated that SCI causes an upregulation of Connexin43, which is decreased by treatment with Peptide5 (Mao et al., 2017). We therefore further analysed expression levels of Connexin30, 36 and 47 in the T10 frozen spinal cord sections at 8 and 24 hours following injury.

Protein levels of Connexin30, 36 and 47 were measured by mean GSV of immunohistochemistry labelling intensity in both grey and white matter at 3.5 and $7 \mathrm{~mm}$ distal to the lesion centre and the epicentre of the lesion. At all anatomical locations, there were no statistically significant differences in Connexin30 protein levels between groups in both grey $(7 \mathrm{~mm}: 31.28 \pm 3.14,3.5 \mathrm{~mm}: 30.67 \pm 3.08$, Epicentre: $35.38 \pm 4.27)$ and white matter ( $7 \mathrm{~mm}: 17.19 \pm 2.00,3.5 \mathrm{~mm}: 17.50 \pm 2.43$, Epicentre: $17.35 \pm 2.69)$ (Figure 5). The expression levels of Connexin36 were also not significantly different between groups in either grey (7 mm: $21.26 \pm 1.91,3.5 \mathrm{~mm}: 21.11 \pm 1.99$, Epicentre: $21.55 \pm 1.88)$ or white matter $(7 \mathrm{~mm}: 10.82 \pm 1.35,3.5 \mathrm{~mm}: 11.11 \pm 1.45$, Epicentre: $11.78 \pm 1.11)$ (Figure 6). Similarly, there were no statistically significant differences found in Connexin47 protein levels between groups in both grey $(7 \mathrm{~mm}: 35.56 \pm 1.40,3.5 \mathrm{~mm}: 35.64 \pm 1.70$, Epicentre: $35.37 \pm 2.13)$ and white matter $(7 \mathrm{~mm}: 23.52 \pm 1.39,3.5 \mathrm{~mm}: 23.22 \pm 1.26$, Epicentre: 22.31 \pm 2.72 ) (Figure 7).

\section{Cytokine profile in the plasma}

To evaluate whether systemic delivery of Peptide5 may affect peripheral immune responses, we tested the cytokine profile in plasma samples removed from the rats at 24 hours after injury. Using a multiplex assay for rat plasma samples, nine of the analytes tested showed reportable plasma values. These were IL (interleukin)-5, IL-18, chemokine (C-C motif) ligand 5 (RANTES), chemokine (C-X-C motif) ligand 1 (GROKC), monocyte chemoattractant protein 1 (MCP-1), macrophage inflammatory protein $3 \alpha$ (MIP-3A), 
erythropoietin (EPO), macrophage colony-stimulating factor (M-CSF) and vascular endothelial growth factor (VEGF). Table 2 summarises the mean concentration for each of the analytes in $\mathrm{pg} / \mathrm{ml}$. No significant differences were detected between groups for any of the plasma cytokine analytes using a one-way ANOVA.

\section{Discussion}

The data presented here shows that the systemic administration of Peptide5 to rats did not appear to cause any off-target or adverse effects in either control or SCI animals. As anticipated, Peptide5 was delivered to the lesion area of the spinal cord. This is because the permeability of the blood spinal cord-barrier (BSCB) is significantly increased following traumatic SCI (Bilgen et al. 2002; Gordh et al. 2006; Popovich et al. 1996) and the capillary bed at the lesion area is compromised (Figley et al. 2014; Soubeyrand et al. 2014). This provides an opportunity for Peptide5 to leak from the disrupted blood vessels of the vascular system into the damaged spinal cord tissue. Under normal physiological conditions, the selective permeability of the blood brain and/or spinal cord barrier prevents small molecules $(<10 \mathrm{kDa})$ from entering the central nervous system (CNS) tissue (Habgood et al. 2007; Popovich et al. 1996). As shown in the current study, the FITC-labelled Peptide5 $(<2 \mathrm{kDa})$ was not detected in the non-injured tissue of the CNS.

\section{Peptide5 in the spinal cord tissue}

Peptide 5 is synthesised to mimic a sequence on the extracellular loop 2 of Connexin43 (Kim et al. 2017). Systemic administration of Peptide5 has been shown to successfully regulate Connexin43 protein expression levels and hemichannel closure in the injured spinal cord (Mao et al. 2017), and we now show here that the protein (gap junction labelling) levels of Connexin 30, 36 and 47 were unaltered using immunohistochemistry. Connexin30, abundantly expressed on astrocytes, is found in astrocyte/astrocyte gap junctions (Nagy et al. 
1999; Rash et al. 2001) and has not been reported change in the spinal cord following traumatic injury. In the current study, there was no evidence that the Connexin30 expression levels and patterns altered in response to SCI or Peptide5 treatment. Even though the expression of Connexin30 and 43 is tightly regulated by neurons (Koulakoff et al. 2008), further studies should investigate the interaction and relationship between these two main astrocytic connexins. Connexin36 is the major connexin found in neuron/neuron gap junctions (Lee et al. 2005; Rash et al. 2000; Rash et al. 2001). In agreement with a previous study (Lee et al. 2005), the current study demonstrated that Connexin36 expression surrounding the lesion in the spinal cord did not alter in response to traumatic injury, nor was it affected by Peptide5 treatment. However, Yates et al. (2008) observed a downregulation of Connexin36 protein at the lumber enlargement distal to the injury area at 7 days after a complete T10 transection in rats. The change in Connexin36 protein below the lesion level, in association with decreased electrical coupling, has been suggested to contribute to hyperreflexia and spasticity after SCI (Yates et al. 2008; Yates et al. 2011). However, the effect of Peptide5 distal to the lesion was not examined specifically in the current study. Connexin47, localised to oligodendrocytes, is known to dock with Connexin43 on astrocytes in astrocyte/oligodendrocyte gap junctions (Kamasawa et al. 2005; Kleopa et al. 2004; Li et al. 2004). Connexin47 expression has not been reported to change following a traumatic event on the spinal cord, despite increased expression of Connexin 43 on astrocytes. This may suggest that the upregulated Connexin43 following SCI contributes primarily to the gap junctions between astrocytes rather than between astrocytes and oligodendrocytes.

\section{Peptide5 in other tissues}

There was no evidence of Peptide5 entering the heart tissue, indicating that Peptide5 remains in the vascular system rather than affecting the Connexin43 hemichannels on cardiomyocytes. This was further confirmed by the immunohistochemistry studies, showing that both 
Connexin43 protein and phosphorylated Connexin43 protein (hemichannel closure) levels in the heart tissue did not differ between Peptide5 treatment and controls at either 8 or 24 hours following SCI.

Peptide5 has been used for other applications, such as retinal ischaemia (Chen et al. 2015; Chen et al. 2014; Danesh-Meyer et al. 2012), cerebral ischaemia (Davidson et al. 2012b) and in an epileptiform lesion model (Yoon et al. 2010), but potential off-target effects on cardiomyocytes has not been reported. Another Connexin43 mimetic peptide, Gap26 (sequence VCYDKSFPISHVR), synthesised to modulate Connexin43 hemichannels on cardiomyocytes. has been reported to protect the intact heart against ischaemia reperfusion injury ex vivo (Hawat et al. 2010) and the ischemic heart against myocardial infarction in vivo (Hawat et al. 2012). Given these results, it is not likely that systemically delivered Peptide5 will cause any adverse impact on intact heart tissue.

Peptide5, via systemic delivery, is not expected to affect lung tissue in vivo since Connexin43 expression has not been reported in pneumocytes (Chang et al. 2013; Ishikawa et al. 2012; Márquez-Rosado et al. 2012; Rottlaender et al. 2010), but it maybe present in the blood vessels throughout the respiratory system (Rummery et al. 2002). In the current study, Connexin43 was not detected in lung sections by fluorescent immunohistochemistry staining in any group, but there was FITC-P5 present in the tissue sections of SCI and Sham animals, as well as abnormal histological morphology shown by H\&E staining in all groups.

FITC-labelled Peptide5 found in the spleen and kidney tissue was not unexpected. The spleen, a critically important immune organ combining both innate and adaptive immunities, is responsible for capturing and destroying pathogens and foreign bodies (Cesta 2006; Mebius and Kraal 2005). Peptide5, as a foreign body appears to be detected by the antigen-presenting cells in the spleen, such as dendritic cells, and may be being cleared by phagocytosis (Eloranta and Alm 1999; Lopes-Carvalho and Kearney 2004; van Rooijen 1990). However, 
Peptide5 could also be filtered through the glomeruli into urine, as the high permeability of the glomerular capillary wall allows the molecules smaller than albumin to pass into the filtrate (Lund et al. 2003; Sandoval et al. 2012; Venkatachalam and Rennke 1978). Similarly, a few recent studies of tissue distribution observed the accumulation of other pharmaceutical and biological agents in the spleen and their excretion through urine (Aubert et al. 2012; Baek et al. 2012; Cho et al. 2013; Jasim et al. 2015; Liang et al. 2013).

\section{Systemic effects of Peptide5}

While it is expected that there would be inflammatory changes, such as increase in proinflammatory cytokines, at the site of injury in the spinal cord tissue, the effects of SCI on circulating cytokines is less clear. We therefore investigated SCI and Peptide5 treatments alters systemic cytokine profile. Our results demonstrate that there was no systemic inflammatory response as a result of either the SCI or the Peptide5 treatment. This further supports that there are no off-target effects of Peptide5 that might result in wide spread inflammatory changes. We have, however, previously shown that IL-1 $\beta$ and TNF $\alpha$ are significantly up regulated in spinal cord itself after injury (O'Carroll et al. 2013). This does not appear to translate to significant changes in plasma cytokines, however, at least at the 24 hours post-injury time point. Prior to clinical translation further toxicity studies will be required to determine if peptide5 causes any subtler immunomodulatory changes. Neither sham animals treated with Peptide5 nor animals treated with the SP control showed any evidence of adverse effects in this study or in other studies using Peptide5 (Danesh-Meyer et al. 2012; Davidson et al. 2012a). Further, there were no statistically significant differences between Peptide5 and SP-treated sham animals in previously undertaken molecular, cellular and behavioural analyses (Mao et al. 2017). It is suggested that Peptide5 rarely travels to the uninjured tissue, nor should it act globally on gap junctions in other organs at the low concentration used in the current study. While, higher doses may prove adverse, as reported 
for example in a foetal model of ischaemia in sheep (Davidson et al. 2013b), systemic effects of low dose Peptide5 have not been reported in any in vivo models when delivered locally (Chen et al. 2015; Chen et al. 2014; Danesh-Meyer et al. 2012; Davidson et al. 2015; Davidson et al. 2013a; Davidson et al. 2013b; Davidson et al. 2014; O'Carroll et al. 2013), or systemically (Danesh-Meyer et al., 2012; Mao et al., 2017). Similarly, Hawat et al. (2012) did not report any systemic or adverse events after intravenous injection of another Connexin43 mimetic peptide, Gap26, into rats with myocardial infarction.

Given the short timeframe of 24 hours in the current study, further investigation is required to determine whether there are any the long-term effects of systemic Peptide5 treatment on the injured spinal cord and other uninjured tissues, and it will be necessary to establish a full toxicity profile for systemic Peptide5 delivery prior to human testing. Our results, however, suggest that the systemic administration of Peptide 5 is unlikely to result in deleterious effects on the non-injured spinal cord, other major organs and systemic inflammatory responses, and this peptide is expected offer a safe treatment option for traumatic SCI.

\section{Acknowledgements}

This work was supported by the Australasian Spinal Cord Injury Network and the CatWalk Spinal Cord Injury Trust New Zealand. YM was supported by a University of Technology Sydney Doctoral Scholarship and an Australian Government Research Training Program Scholarship.

\section{Author Disclosure Statement}

Prof. Colin Green is a founding scientist of CoDa Therapeutics, Inc. (USA) and OcuNexus, Inc. (USA) which hold intellectual property rights related to Peptide5. For the remaining authors, no competing financial interests exist. 


\section{References}

Abdelaziz RR, Elkashef WF, Said E (2016) Tadalafil reduces airway hyperactivity and protects against lung and respiratory airways dysfunction in a rat model of silicosis International Immunopharmacology 40:530-541

Abudara V et al. (2014) The connexin43 mimetic peptide Gap19 inhibits hemichannels without altering gap junctional communication in astrocytes Frontiers in cellular neuroscience 8:306

Aubert N, Ameller T, Legrand J-J (2012) Systemic exposure to parabens: pharmacokinetics, tissue distribution, excretion balance and plasma metabolites of [14 C]-methyl-, propyl-and butylparaben in rats after oral, topical or subcutaneous administration Food and Chemical Toxicology 50:445-454

Baek $M$ et al. (2012) Pharmacokinetics, tissue distribution, and excretion of zinc oxide nanoparticles International Journal of Nanomedicine 7:3081-3097

Bilgen M, Dogan B, Narayana PA (2002) In vivo assessment of blood-spinal cord barrier permeability: serial dynamic contrast enhanced MRI of spinal cord injury Magnetic Resonance Imaging 20:337-341

Cesta MF (2006) Normal structure, function, and histology of the spleen Toxicologic Pathology 34:455-465

Chang H-M, Cheng J-C, Leung PC (2013) Theca-derived BMP4 and BMP7 down-regulate connexin43 expression and decrease gap junction intercellular communication activity in immortalized human granulosa cells The Journal of Clinical Endocrinology and Metabolism 98:E437-E445

Chang Y-c, Chang H-Y, Hahn R, Lee E, Svoboda K, Gordon M, Gerecke D (2015) Connexin 43 antisense therapy modulates connexin expression and wound repair in nitrogen mustard injured mouse skin The FASEB Journal 29:876-873

Chen YS, Green CR, Teague R, Perrett J, Danesh-Meyer HV, Toth I, Rupenthal ID (2015) Intravitreal injection of lipoamino acid-modified connexin43 mimetic peptide enhances neuroprotection after retinal ischemia Drug Delivery and Translational Tesearch 5:480-488

Chen YS, Green CR, Wang K, Danesh-Meyer HV, Rupenthal ID (2014) Sustained intravitreal delivery of connexin43 mimetic peptide by poly (d, I-lactide-co-glycolide) acid microand nanoparticles-Closing the gap in retinal ischaemia European Journal of Pharmaceutics and Biopharmaceutics doi:10.1016/j.ejpb.2014.12.005

Chevallier D, Carette D, Segretain D, Gilleron J, Pointis G (2013) Connexin 43 a check-point component of cell proliferation implicated in a wide range of human testis diseases Cellular and Molecular Life Sciences 70:1207-1220

Cho W-S, Kang B-C, Lee JK, Jeong J, Che J-H, Seok SH (2013) Comparative absorption, distribution, and excretion of titanium dioxide and zinc oxide nanoparticles after repeated oral administration Particle and Fibre Toxicology 10:1

Danesh-Meyer HV et al. (2012) Connexin43 mimetic peptide reduces vascular leak and retinal ganglion cell death following retinal ischaemia Brain 135:506-520

Davidson J, Green C, Bennet L, Gunn A (2015) Battle of the hemichannels-connexins and pannexins in ischemic brain injury International Journal of Developmental Neuroscience 45:66-74 
Davidson J, Green C, Nicholson L, Bennet L, Gunn A (2013a) Connexin hemichannel blockade is neuroprotective after, but not during, global cerebral ischemia in near-term fetal sheep Experimental Neurology 248:301-308

Davidson J, R Green C, Bennet L, FB Nicholson L, Danesh-Meyer H, J O'Carroll S, J Gunn A (2013b) A key role for connexin hemichannels in spreading ischemic brain injury Current Drug Targets 14:36-46

Davidson JO, Drury PP, Green CR, Nicholson LF, Bennet L, Gunn AJ (2014) Connexin hemichannel blockade is neuroprotective after asphyxia in preterm fetal sheep PLoS One 9:e96558

Davidson JO et al. (2012a) Connexin hemichannel blockade improves outcomes in a model of fetal ischemia Annals of Neurology 71:121-132

Davidson JO, Green CR, Nicholson LF, Bennet L, Gunn AJ (2012b) Deleterious effects of high dose connexin 43 mimetic peptide infusion after cerebral ischaemia in near-term fetal sheep International Journal of Molecular Sciences 13:6303-6319

Decrock E et al. (2015) Connexin and pannexin signaling pathways, an architectural blueprint for CNS physiology and pathology? Cellular and Molecular Life Sciences 72:2823-2851

Deng Z-H et al. (2014) Inhibition of the connexin 43 elevation may be involved in the neuroprotective activity of leptin against brain ischemic injury Cellular and molecular neurobiology 34:871-879

Dorshkind K, Green L, Godwin A, Fletcher W (1993) Connexin-43-type gap junctions mediate communication between bone marrow stromal cells Blood 82:38-45

Dürig J et al. (2000) Intercellular communication between bone marrow stromal cells and CD34+ haematopoietic progenitor cells is mediated by connexin 43 -type gap junctions British Journal of Haematology 111:416-425

Eloranta M, Alm G (1999) Splenic Marginal Metallophilic Macrophages and Marginal Zone Macrophages are the Major Interferon- / Producers in Mice upon Intravenous Challenge with Herpes Simplex Virus Scandinavian Journal of Immunology 49:391394

Faigle M, Seessle J, Zug S, El Kasmi KC, Eltzschig HK (2008) ATP release from vascular endothelia occurs across $\mathrm{C} \times 43$ hemichannels and is attenuated during hypoxia PLoS One 3:e2801

Figley SA, Khosravi R, Legasto JM, Tseng Y-F, Fehlings MG (2014) Characterization of vascular disruption and blood-spinal cord barrier permeability following traumatic spinal cord injury Journal of neurotrauma 31:541-552

Gauter-Fleckenstein B et al. (2014) Robust rat pulmonary radioprotection by a lipophilic Mn $\mathrm{N}$-alkylpyridylporphyrin, MnTnHex-2-PyP 5+ Redox Biology 2:400-410

Gordh T, Chu H, Sharma HS (2006) Spinal nerve lesion alters blood-spinal cord barrier function and activates astrocytes in the rat Pain 124:211-221

Gourdie RG, Severs NJ, Green CR, Rothery S, Germroth P, Thompson RP (1993) The spatial distribution and relative abundance of gap-junctional connexin 40 and connexin43 correlate to functional properties of components of the cardiac atrioventricular conduction system Journal of Cell Science 105:985-991

Gu Y, Wu G, Wang X, Wang X, Wang Y, Huang C (2014) Artemisinin prevents electric remodeling following myocardial infarction possibly by upregulating the expression of connexin 43 Molecular Medicine Reports 10:1851-1856 
Guo H, Acevedo P, Parsa FD, Bertram JS (1992) Gap-junctional protein connexin 43 is expressed in dermis and epidermis of human skin: differential modulation by retinoids Journal of Investigative Dermatology 99:460-467

Habgood $\mathrm{M}$ et al. (2007) Changes in blood-brain barrier permeability to large and small molecules following traumatic brain injury in mice European Journal of Neuroscience 25:231-238

Han S et al. (2010) Rescuing vasculature with intravenous angiopoietin-1 and $\alpha v \beta 3$ integrin peptide is protective after spinal cord injury Brain 133:1026-1042

Hawat G, Benderdour M, Rousseau G, Baroudi G (2010) Connexin 43 mimetic peptide Gap26 confers protection to intact heart against myocardial ischemia injury Pflügers ArchivEuropean Journal of Physiology 460:583-592

Hawat G, Hélie P, Baroudi G (2012) Single intravenous low-dose injections of connexin 43 mimetic peptides protect ischemic heart in vivo against myocardial infarction Journal of Molecular and Cellular Cardiology 53:559-566

Herrera JJ, Nesic O, Narayana PA (2009) Reduced vascular endothelial growth factor expression in contusive spinal cord injury Journal of neurotrauma 26:995-1003

Ishikawa S et al. (2012) Role of connexin-43 in protective PI3K-Akt-GSK-3 $\beta$ signaling in cardiomyocytes American Journal of Physiology-Heart and Circulatory Physiology 302: $\mathrm{H} 2536-\mathrm{H} 2544$

Jasim DA, Ménard-Moyon C, Bégin D, Bianco A, Kostarelos K (2015) Tissue distribution and urinary excretion of intravenously administered chemically functionalized graphene oxide sheets Chemical Science 6:3952-3964

Kamasawa N, Sik A, Morita M, Yasumura T, Davidson K, Nagy J, Rash J (2005) Connexin-47 and connexin-32 in gap junctions of oligodendrocyte somata, myelin sheaths, paranodal loops and Schmidt-Lanterman incisures: implications for ionic homeostasis and potassium siphoning Neuroscience 136:65-86

Kim Y et al. (2017) Characterizing the mode of action of extracellular Connexin43 channel blocking mimetic peptides in an in vitro ischemia injury model Biochimica et Biophysica Acta - General Subjects 1861:68-78

Kleopa KA, Orthmann JL, Enriquez A, Paul DL, Scherer SS (2004) Unique distributions of the gap junction proteins connexin29, connexin32, and connexin47 in oligodendrocytes Glia 47:346-357

Koulakoff A, Ezan P, Giaume C (2008) Neurons control the expression of connexin 30 and connexin 43 in mouse cortical astrocytes Glia 56:1299-1311

Lampe PD, TenBroek EM, Burt JM, Kurata WE, Johnson RG, Lau AF (2000) Phosphorylation of connexin43 on serine368 by protein kinase $C$ regulates gap junctional communication The Journal of cell biology 149:1503-1512

Lee IH, Lindqvist E, Kiehn O, Widenfalk J, Olson L (2005) Glial and neuronal connexin expression patterns in the rat spinal cord during development and following injury Journal of Comparative Neurology 489:1-10 doi:10.1002/cne.20567

Leybaert L, Braet K, Vandamme W, Cabooter L, Martin PE, Evans WH (2003) Connexin channels, connexin mimetic peptides and ATP release Cell Communication and Adhesion 10:251-257

Li MW, Mruk DD, Lee WM, Cheng CY (2010) Connexin 43 is critical to maintain the homeostasis of the blood-testis barrier via its effects on tight junction reassembly Proceedings of the National Academy of Sciences 107:17998-18003 
Li X et al. (2004) Connexin47, connexin29 and connexin32 co-expression in oligodendrocytes and Cx47 association with zonula occludens-1 (ZO-1) in mouse brain Neuroscience 126:611-630

Liang L, Liu X, Wang Q, Cheng S, Zhang S, Zhang M (2013) Pharmacokinetics, tissue distribution and excretion study of resveratrol and its prodrug 3, 5, 4'-tri-Oacetylresveratrol in rats Phytomedicine : international journal of phytotherapy and phytopharmacology 20:558-563

Lin JH et al. (1998) Gap-junction-mediated propagation and amplification of cell injury Nature Neuroscience 1:494-500

Lopes-Carvalho T, Kearney JF (2004) Development and selection of marginal zone B cells Immunological Reviews 197:192-205

Lund U, Rippe A, Venturoli D, Tenstad O, Grubb A, Rippe B (2003) Glomerular filtration rate dependence of sieving of albumin and some neutral proteins in rat kidneys American Journal of Physiology-Renal Physiology 284:F1226-F1234

Mao $Y$ et al. (2017) Systemic administration of Connexin43 mimetic peptide improves functional recovery after traumatic spinal cord Injury in adult Rats Journal of neurotrauma 33:707-719 doi:10.1089/neu.2016.4625

Márquez-Rosado L, Solan JL, Dunn CA, Norris RP, Lampe PD (2012) Connexin43 phosphorylation in brain, cardiac, endothelial and epithelial tissues Biochimica et Biophysica Acta (BBA)-Biomembranes 1818:1985-1992

Mebius RE, Kraal G (2005) Structure and function of the spleen Nature Reviews Immunology 5:606-616

Nagy JI, Patel D, Ochalski PA, Stelmack GL (1999) Connexin30 in rodent, cat and human brain: selective expression in gray matter astrocytes, co-localization with connexin43 at gap junctions and late developmental appearance Neuroscience 88:447-468

Nakase T, Söhl G, Theis M, Willecke K, Naus CC (2004) Increased apoptosis and inflammation after focal brain ischemia in mice lacking connexin43 in astrocytes The American journal of pathology 164:2067-2075

Nesic O, Sundberg LM, Herrera JJ, Mokkapati VU, Lee J, Narayana PA (2010) Vascular endothelial growth factor and spinal cord injury pain Journal of neurotrauma 27:1793-1803

O'Carroll SJ, Alkadhi M, Nicholson LF, Green CR (2008) Connexin43 mimetic peptides reduce swelling, astrogliosis, and neuronal cell death after spinal cord injury Cell Communication and Adhesion 15:27-42

O'Carroll SJ, Gorrie CA, Velamoor S, Green CR, Nicholson LF (2013) Connexin43 mimetic peptide is neuroprotective and improves function following spinal cord injury Neuroscience Research 75:256-267

Orellana JA et al. (2011) ATP and glutamate released via astroglial connexin 43 hemichannels mediate neuronal death through activation of pannexin 1 hemichannels Journal of neurochemistry 118:826-840

Orthmann-Murphy JL, Abrams CK, Scherer SS (2008) Gap junctions couple astrocytes and oligodendrocytes Journal of Molecular Neuroscience 35:101-116

Popovich PG, Horner PJ, Mullin BB, Stokes BT (1996) A quantitative spatial analysis of the blood-spinal cord barrier: I. Permeability changes after experimental spinal contusion injury Experimental Neurology 142:258-275

Rash J, Staines W, Yasumura T, Patel D, Furman C, Stelmack G, Nagy J (2000) Immunogold evidence that neuronal gap junctions in adult rat brain and spinal cord contain 
connexin-36 but not connexin-32 or connexin-43 Proceedings of the National Academy of Sciences 97:7573-7578

Rash J, Yasumura T, Davidson K, Furman C, Dudek F, Nagy J (2001) Identification of cells expressing $\mathrm{C} \times 43, \mathrm{Cx} 30, \mathrm{C} \times 26, \mathrm{Cx} 32$ and $\mathrm{C} \times 36$ in gap junctions of rat brain and spinal cord Cell Communication and Adhesion 8:315-320

Rash JE, Yasumura T, Dudek F (1998) Ultrastructure, histological distribution, and freezefracture immunocytochemistry of gap junctions in rat brain and spinal cord Cell Biology International 22:731-749

Rottlaender D et al. (2010) Connexin 43 acts as a cytoprotective mediator of signal transduction by stimulating mitochondrial K ATP channels in mouse cardiomyocytes The Journal of Clinical Investigation 120:1441-1453

Rummery NM, Hickey H, McGurk G, Hill CE (2002) Connexin37 is the major connexin expressed in the media of caudal artery Arteriosclerosis, Thrombosis, and Vascular Biology 22:1427-1432

Sandoval RM et al. (2012) Multiple factors influence glomerular albumin permeability in rats Journal of the American Society of Nephrology 23:447-457

Scemes E, Suadicani SO, Spray DC (2000) Intercellular communication in spinal cord astrocytes: fine tuning between gap junctions and $\mathrm{P} 2$ nucleotide receptors in calcium wave propagation The Journal of Neuroscience 20:1435-1445

Soubeyrand M, Badner A, Vawda R, Chung YS, Fehlings MG (2014) Very high resolution ultrasound imaging for real-time quantitative visualization of vascular disruption after spinal cord injury Journal of neurotrauma 31:1767-1775

Steger K, Tetens F, Bergmann M (1999) Expression of connexin 43 in human testis Histochemistry and Cell Biology 112:215-220

Stehberg J et al. (2012) Release of gliotransmitters through astroglial connexin 43 hemichannels is necessary for fear memory consolidation in the basolateral amygdala The FASEB Journal 26:3649-3657

Tada J, Hashimoto K (1997) Ultrastructural localization of gap junction protein connexin 43 in normal human skin, basal cell carcinoma, and squamous cell carcinoma Journal of Cutaneous Pathology 24:628-635

Theriault E, Frankenstein U, Hertzberg E, Nagy J (1997) Connexin43 and astrocytic gap junctions in the rat spinal cord after acute compression injury Journal of Comparative Neurology 382:199-214

Thompson RJ, Zhou N, MacVicar BA (2006) Ischemia opens neuronal gap junction hemichannels Science 312:924-927

Tonkin RS, Mao Y, O'Carroll SJ, Nicholson LF, Green CR, Gorrie CA, Moalem-Taylor G (2015) Gap junction proteins and their role in spinal cord injury Frontiers in Molecular Neuroscience 7

van den Brule $S$ et al. (2014) Nanometer-long Ge-imogolite nanotubes cause sustained lung inflammation and fibrosis in rats Particle and Fibre Toxicology 11:67

Van Kempen M, Fromaget C, Gros D, Moorman A, Lamers W (1991) Spatial distribution of connexin43, the major cardiac gap junction protein, in the developing and adult rat heart Circulation Research 68:1638-1651

van Rooijen N (1990) Antigen processing and presentation in vivo: the microenvironment as a crucial factor Immunology Today 11:436-439

Venkatachalam MA, Rennke HG (1978) The structural and molecular basis of glomerular filtration Circulation Research 43:337-347 
Yamamoto T, Ochalski A, Hertzberg E, Nagy J (1990) LM and EM immunolocalization of the gap junctional protein connexin 43 in rat brain Brain Besearch 508:313-319

Yates C, Charlesworth A, Allen S, Reese N, Skinner R, Garcia-Rill E (2008) The onset of hyperreflexia in the rat following complete spinal cord transection Spinal Cord 46:798-803

Yates C, Garrison K, Reese N, Charlesworth A, Garcia-Rill E (2011) Novel mechanism for hyper-reflexia and spasticity Progress in Brain Research 188:167

Ye ZC, Wyeth MS, Baltan-Tekkok S, Ransom BR (2003) Functional hemichannels in astrocytes: a novel mechanism of glutamate release The Journal of Neuroscience 23:3588-3596

Yoon JJ, Green CR, O'Carroll SJ, Nicholson LF (2010) Dose-dependent protective effect of connexin43 mimetic peptide against neurodegeneration in an ex vivo model of epileptiform lesion Epilepsy Research 92:153-162

Zhang C, Li Y, Chen J, Gao Q, Zacharek A, Kapke A, Chopp M (2006) Bone marrow stromal cells upregulate expression of bone morphogenetic proteins 2 and 4 , gap junction protein connexin-43 and synaptophysin after stroke in rats Neuroscience 141:687695 
Table 1 Summary of animal cohorts and tissue samples obtained.

\begin{tabular}{|c|c|c|c|c|c|}
\hline Cohort & Condition & Treatment & $\begin{array}{l}\text { Survival } \\
\text { Time }\end{array}$ & Sample & Experiment \\
\hline I & $\begin{array}{c}\text { SCI } \\
\text { or } \\
\text { Intact } \\
\text { control }\end{array}$ & $\begin{array}{l}\text { One dose of } \\
\text { FITC-P5 }\end{array}$ & $\begin{array}{l}2 \text { Hours } \\
4 \text { Hours }\end{array}$ & $\begin{array}{l}\text { Fresh spinal cord at } \mathrm{T} 10 \text { and } \\
\text { cervical, brain, heart, lung, } \\
\text { liver, spleen and kidney }\end{array}$ & $\begin{array}{c}\text { Histology } \\
(\mathrm{n}=4 \text { per group })\end{array}$ \\
\hline \multirow{3}{*}{ II } & $\mathrm{SCI}$ & $\begin{array}{l}\text { Three doses } \\
\text { of P5 or SP }\end{array}$ & 8 Hours & $\begin{array}{l}\text { PFA fixed spinal cord at T10, } \\
\text { heart and lung }\end{array}$ & $\begin{array}{l}\text { H\&E and IHC } \\
(\mathrm{n}=3 \text { per group })\end{array}$ \\
\hline & $\begin{array}{l}\text { SCI } \\
\text { or } \\
\text { Sham }\end{array}$ & $\begin{array}{l}\text { Three doses } \\
\text { of P5 or SP }\end{array}$ & 24 hours & $\begin{array}{l}\text { PFA fixed spinal cord at } \mathrm{T} 10, \\
\text { heart and lung } \\
\text { Fresh plasma }\end{array}$ & $\begin{array}{c}\text { H\&E and IHC } \\
(\mathrm{n}=3 \text { per group) } \\
\text { Multiplexes assays } \\
(\mathrm{n}=8 \text { per group) }\end{array}$ \\
\hline & Sham & $\begin{array}{l}\text { One dose of } \\
\text { Saline }\end{array}$ & 24 hours & PFA fixed heart and lung & $\begin{array}{c}\text { H\&E and IHC } \\
(n=3 \text { per group })\end{array}$ \\
\hline
\end{tabular}

IHC: Immunohistochemistry; P5: Peptide5; SCI: Spinal cord injury; SP: Scrambled peptide;

PFA: Paraformaldehyde

Table 2 Comparison of cytokines, chemokines and growth factors in rat plasma 24 hours after injury. There were no significant differences between groups for any of the analytes using a one-way analysis of variance.

\begin{tabular}{|c|c|c|c|c|c|c|c|c|c|}
\hline \multirow{2}{*}{ Group } & \multicolumn{2}{|c|}{ Cytokines (pg/ml) } & \multicolumn{4}{|c|}{ Chemokines (pg/ml) } & \multicolumn{3}{|c|}{ Growth factors (pg/ml) } \\
\hline & IL-5 & IL-18 & RANTES & GROKC & MCP-1 & MIP-3A & EPO & M-CSF & VEGF \\
\hline \multirow{2}{*}{$\begin{array}{c}\text { Sham } \\
\text { P5 }\end{array}$} & 15.45 & 665.32 & 557.39 & 73.79 & 3611.07 & 77.58 & 979.24 & 293.96 & 28.46 \\
\hline & \pm 19.3 & \pm 410.95 & \pm 154.04 & \pm 45.54 & \pm 1131.33 & \pm 55.71 & \pm 1171.65 & \pm 78.17 & \pm 10.98 \\
\hline \multirow{2}{*}{$\begin{array}{l}\text { Sham } \\
\text { SP }\end{array}$} & 20.58 & 1355.64 & 406.40 & 66.80 & 3201.20 & 76.690 & 1305.92 & 296.92 & 29.64 \\
\hline & \pm 22.43 & \pm 513.35 & \pm 361.29 & \pm 26.37 & \pm 606.39 & \pm 55.22 & \pm 879.92 & \pm 67.46 & \pm 7.72 \\
\hline \multirow{2}{*}{$\begin{array}{l}\text { SCl } \\
\text { P5 }\end{array}$} & 28.38 & 736.24 & 525.46 & 79.17 & 2400.42 & 151.44 & 688.42 & 270.78 & 28.38 \\
\hline & \pm 6.08 & \pm 434.68 & \pm 108.66 & \pm 22.45 & \pm 925.75 & \pm 141.11 & \pm 667.94 & \pm 68.64 & \pm 7.99 \\
\hline \multirow{2}{*}{$\begin{array}{l}\mathrm{SCl} \\
\mathrm{SP}\end{array}$} & 15.17 & 574.12 & 266.29 & 41.85 & 2460.00 & 137.59 & 669.20 & 279.32 & 27.34 \\
\hline & \pm 33.42 & \pm 713.69 & \pm 419.72 & \pm 42.57 & \pm 945.97 & \pm 89.35 & \pm 817.03 & \pm 89.23 & \pm 7.82 \\
\hline
\end{tabular}

EPO: Erythropoietin; GROKC: Chemokine (C-X-C motif) ligand 1; IL: Interleukin;

MCP-1: Monocyte chemoattractant protein 1; MIP-3A: Macrophage inflammatory protein $3 \alpha$; M-CSF: Macrophage colony-stimulating factor; P5: Peptide5; SCI: Spinal cord injury;

SP: Scrambled peptide; RANTES: Chemokine (C-C motif) ligand 5;

VEGF: Vascular endothelial growth factor 
Figure 1 Distribution of fluorescein isothiocyanate labelled Peptide5 in intact and spinal cord injury rats.

The fluorescein isothiocyanate (FITC) labelled Peptide5 was shown in green fluorescence. FITC-Peptide5 presented in the lung, spleen and kidney tissue in both normal and SCI animals, as well as the T10 spinal cord in the SCI rats.

Figure 2 Histological morphology and immunohistochemistry staining of Connexin43 and phosphorylated Connexin 43 in the heart tissue.

(A) Mayer's Haematoxylin and Eosin staining showed no differences in the histological morphology of cardiac muscle between groups. Scale bar $=150 \mu \mathrm{m}$. (B) Representative images of fluorescent immunohistochemistry staining showed the Connexin43 (green) in the heart tissue. Scale bar $=150 \mu \mathrm{m}$. (C) Representative images of fluorescent immunohistochemistry staining showed the Connexin43 phosphorylation at residue Ser368 (red) in the heart tissue. Scale bar $=150 \mu \mathrm{m}$. (D) Immunohistochemistry analysis showed no statistically significant differences in the level of Connexin43 immunoreactivity in the heart tissue between groups. (E) Immunohistochemistry analysis showed no statistically significant differences in the level of phosphorylated Connexin43 immunoreactivity in the heart tissue between groups. (GSV: greyscale value; P5: Peptide5; p-Connexin43: phosphorylated Connexin43; SCI: spinal cord injury; SP: control scrambled peptide)

Figure 3 Histological morphology and immunohistochemistry staining of Connexin 43 in the lung tissue.

Mayer's Haematoxylin and Eosin staining showed no differences in histological morphology of alveolar tissue between groups. Scale bar $=150 \mu \mathrm{m}$. (P5: Peptide5; SCI: spinal cord injury; SP: control scrambled peptide)

Figure 4 Immunohistochemistry co-labelling of major connexin proteins and neural markers at 8 hours following spinal cord injury.

(A) Connexin43 protein (red) was associated with astrocytes (yellow arrow) labelled by glial fibrillary acidic protein (GFAP) (green). (B) Connexin30 protein (red) was associated with astrocytes (white arrow) labelled by GFAP (green). (C) Neurons (yellow arrow heads) labelled by neuronal nuclear antigen $(\mathrm{NeuN})$ (red) was co-labelled with Connexin36 protein (green). (D) Connexin47 protein (red) was associated with oligodendrocytes (white arrow heads) labelled by oligodendrocyte specific protein (OSP) (green). All nuclei were counterstained by Hoechst in blue.

Figure 5 Immunohistochemistry staining of Connexin30 in rat spinal cord at 8 and 24 hours following injury.

(A) Representative images of Connexin30 immunofluorescence (green) at the epicentre of the lesion. Scale bar $=40 \mu \mathrm{m}$. (B) Immunohistochemistry analysis showed the Connexin30 protein levels in both grey and white matter at 3.5 and $7 \mathrm{~mm}$ distal to the lesion centre and the epicentre of the lesion without any significant differences between groups. (GSV: greyscale value; P5: Peptide5; SCI: spinal cord injury; SP: control scrambled peptide)

Figure 6 Immunohistochemistry staining of Connexin36 in rat spinal cord at 8 and 24 hours following injury.

(A) Representative images of Connexin36 immunofluorescence (green) at the epicentre of the lesion. Scale bar $=40 \mu \mathrm{m}$. (B) Immunohistochemistry analysis showed the Connexin36 protein levels in both grey and white matter at 3.5 and $7 \mathrm{~mm}$ distal to the lesion centre and 
the epicentre of the lesion without any significant differences between groups. (GSV: greyscale value; P5: Peptide5; SCI: spinal cord injury; SP: control scrambled peptide)

Figure 7 Immunohistochemistry staining of Connexin47 in rat spinal cord at 8 and 24 hours following injury.

(A) Representative images of Connexin47 immunofluorescence (green) at the epicentre of the lesion. Scale bar $=40 \mu \mathrm{m}$. (B) Immunohistochemistry analysis showed the Connexin 47 protein levels in both grey and white matter at 3.5 and $7 \mathrm{~mm}$ distal to the lesion centre and the epicentre of the lesion without any significant differences between groups. (GSV: greyscale value; P5: Peptide5; SCI: spinal cord injury; SP: control scrambled peptide) 
Spinal Cord - T10

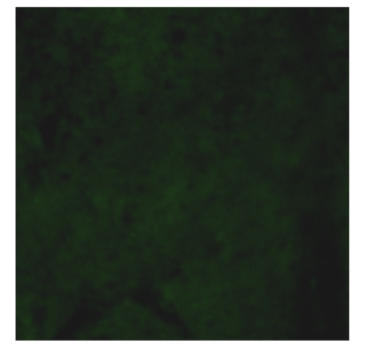

Normal (-)

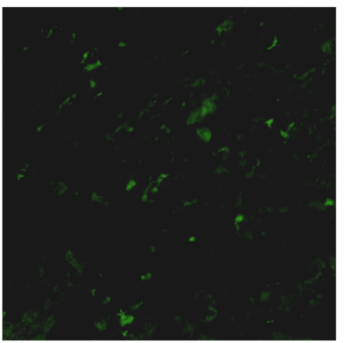

SCI (+)

Lung

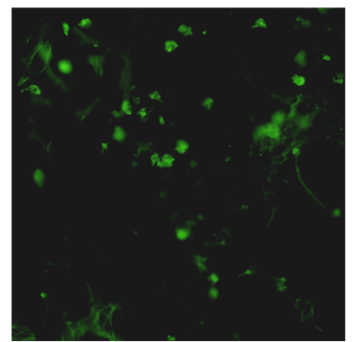

Normal (+)

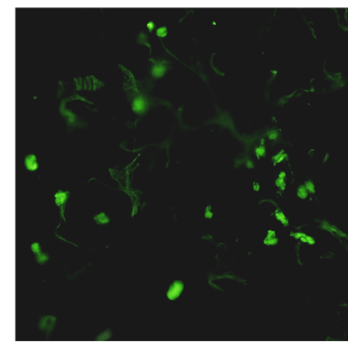

SCI (+)

Spleen

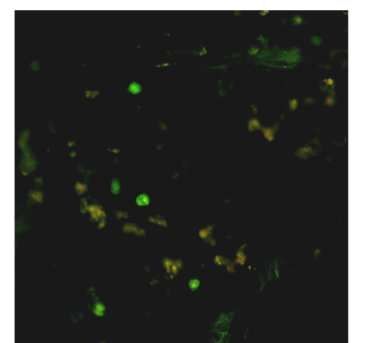

Normal (+)

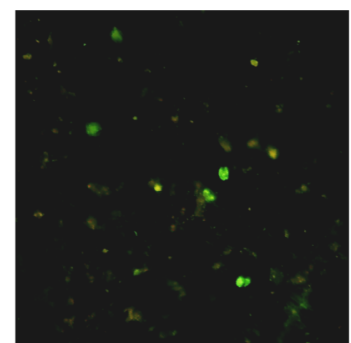

SCI (+)

Kidney

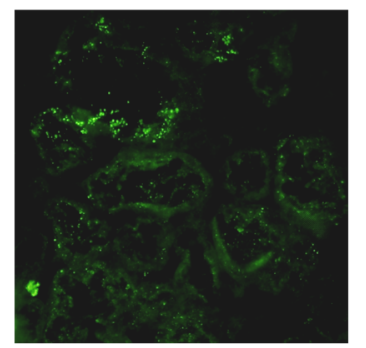

Normal (+)

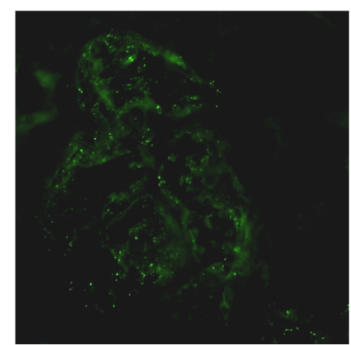

SCI (+)
Spinal Cord - Cervical

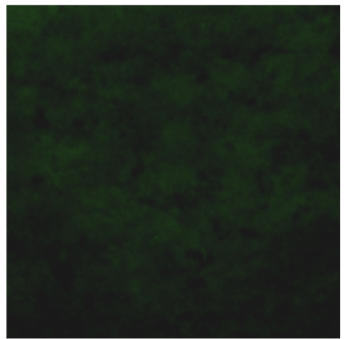

Normal (-)

SCI (-)

Brain

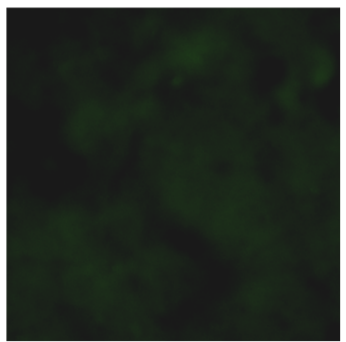

Normal (-)

SCI (-)

Heart

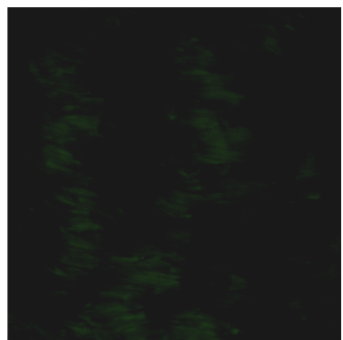

Normal (-)

Liver

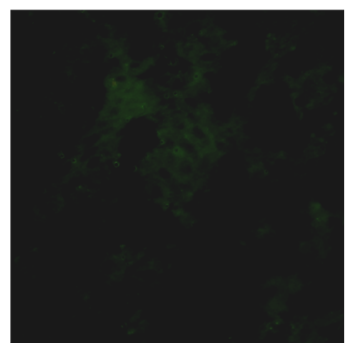

Normal (-)
SCI (-)
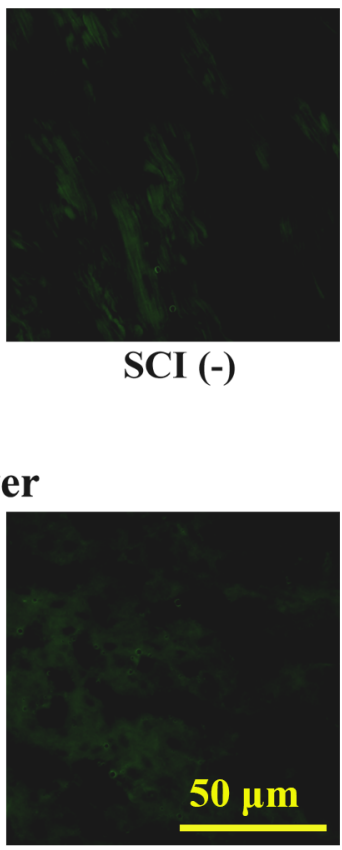

SCI (-) 

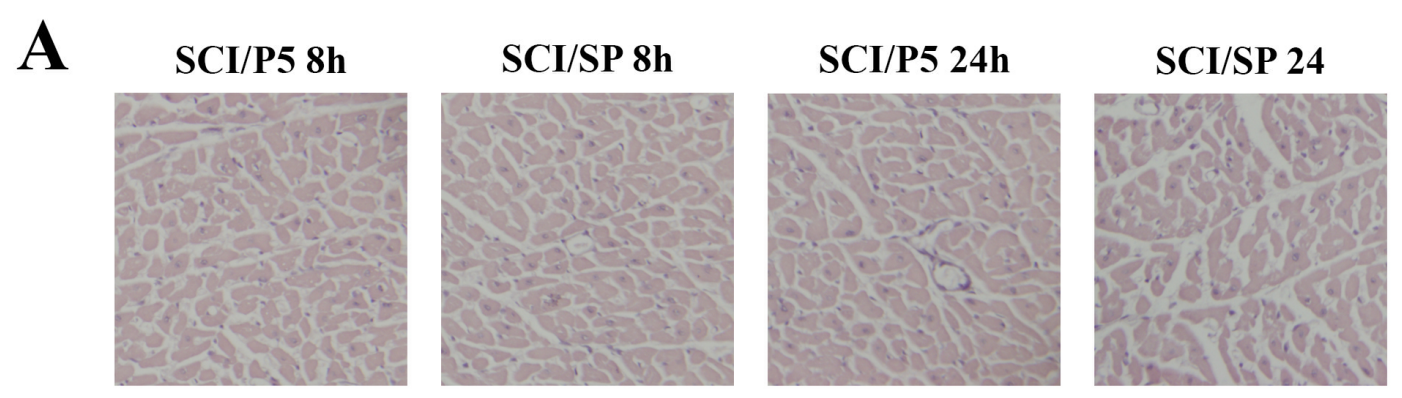

Sham/Saline 24h

B
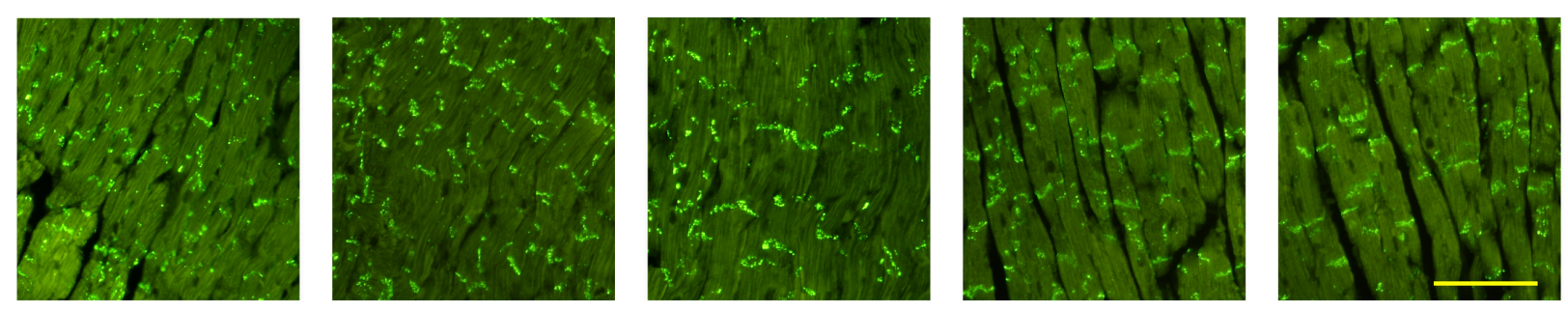

C
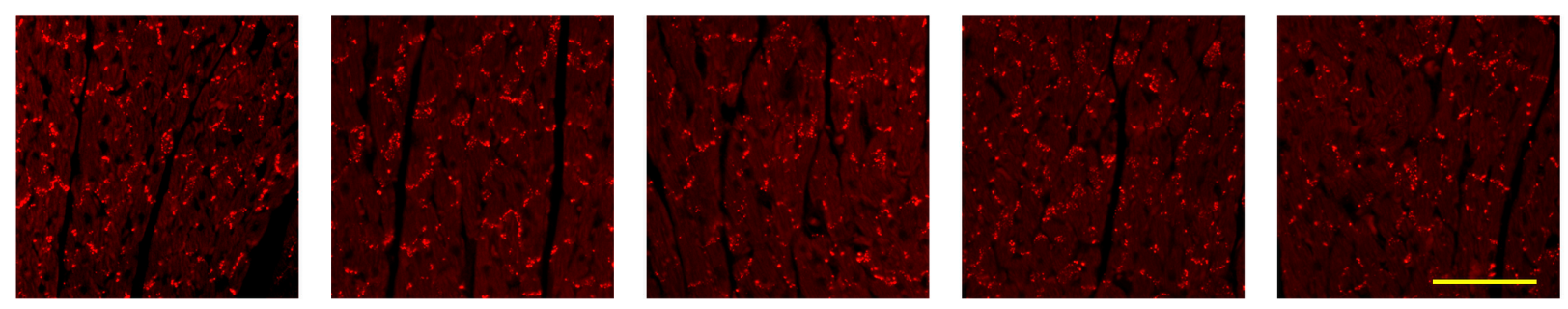

D
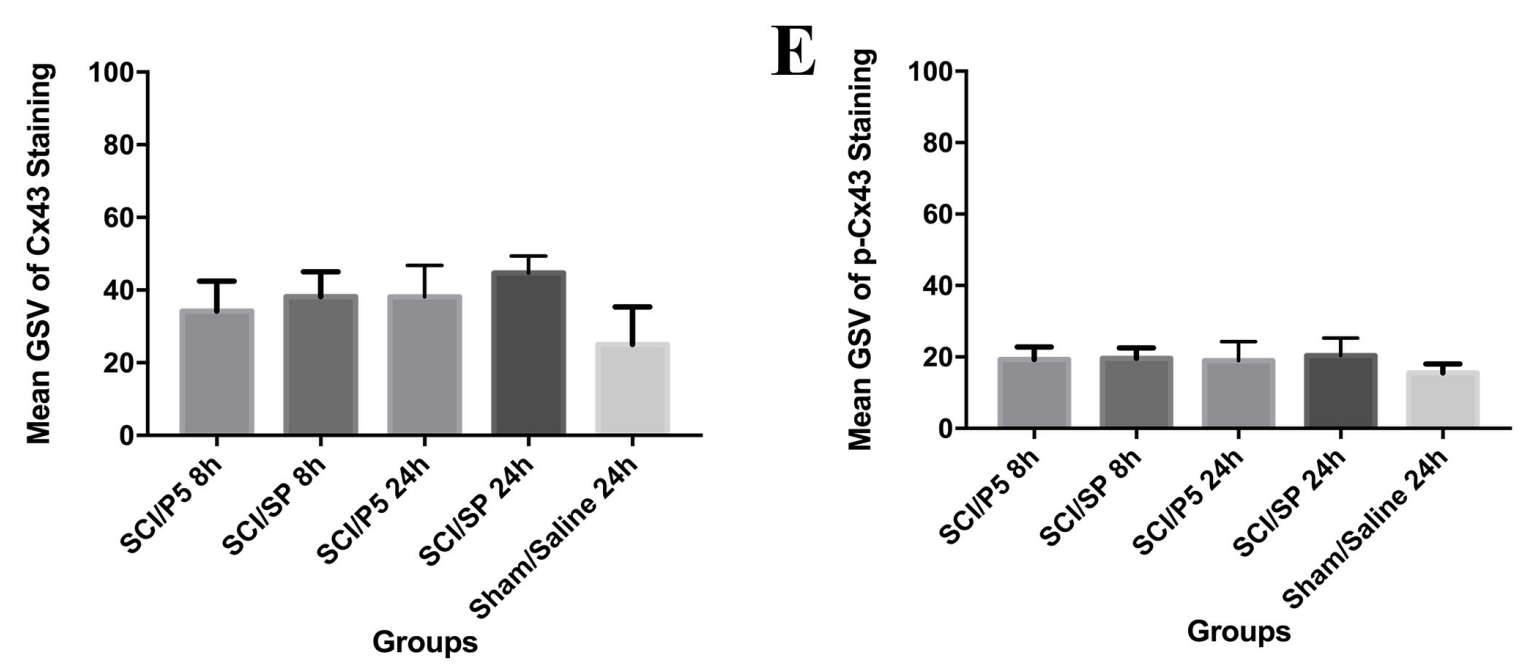

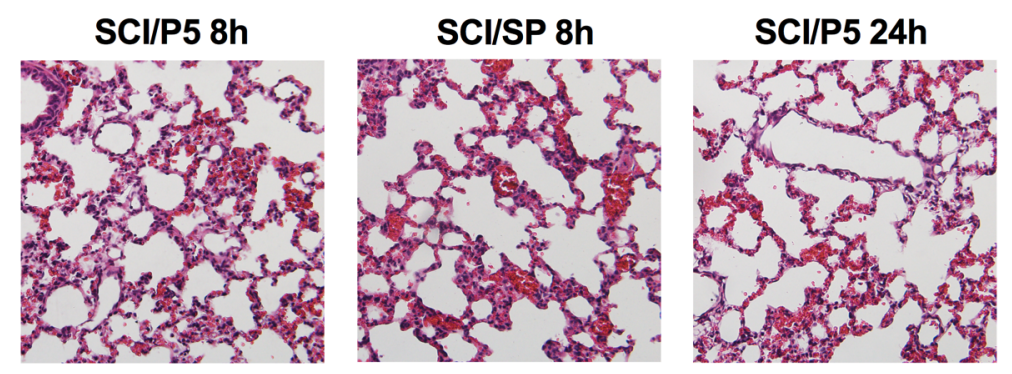

SCI/SP 24h

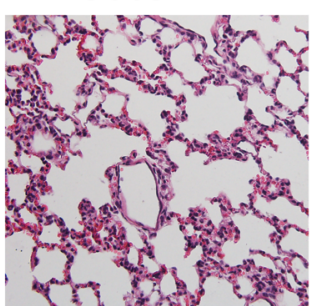

Sham/Saline 24h

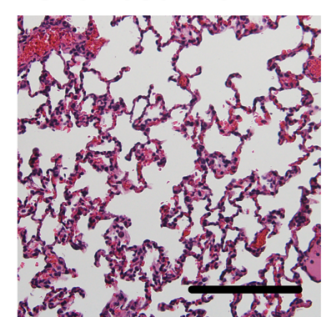



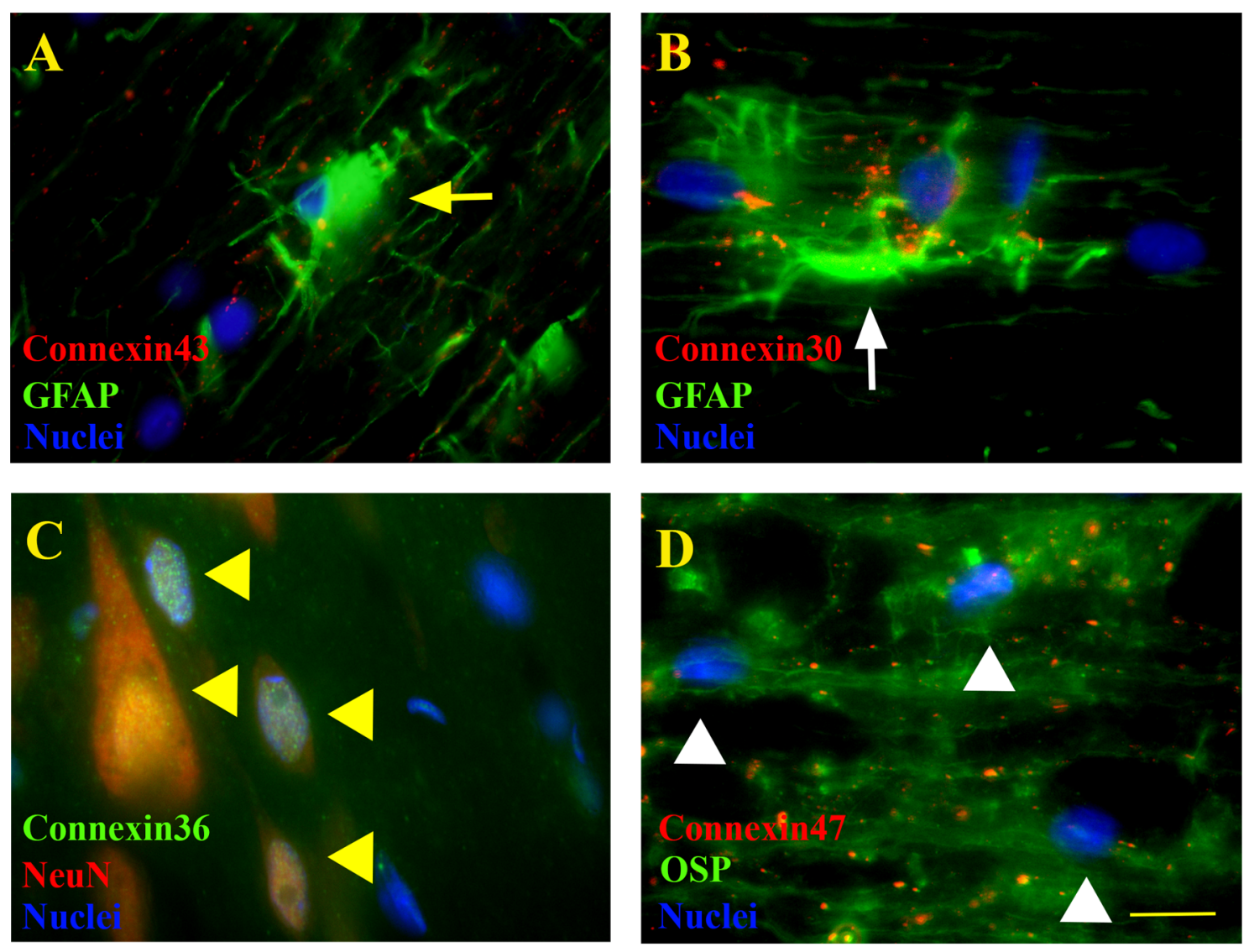


\section{Connexin30}

A

Grey Matter

White Matter

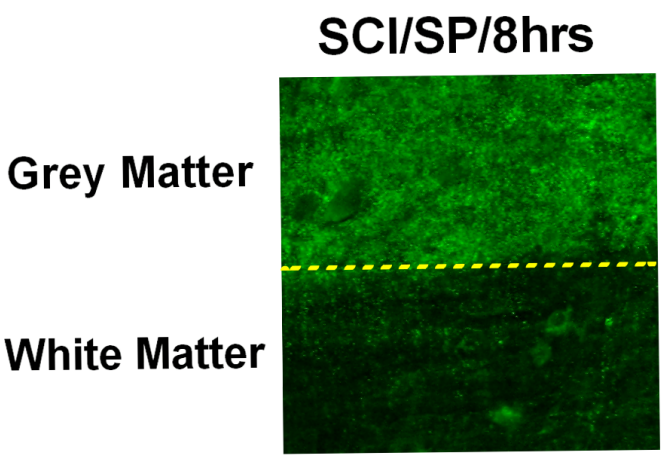

B
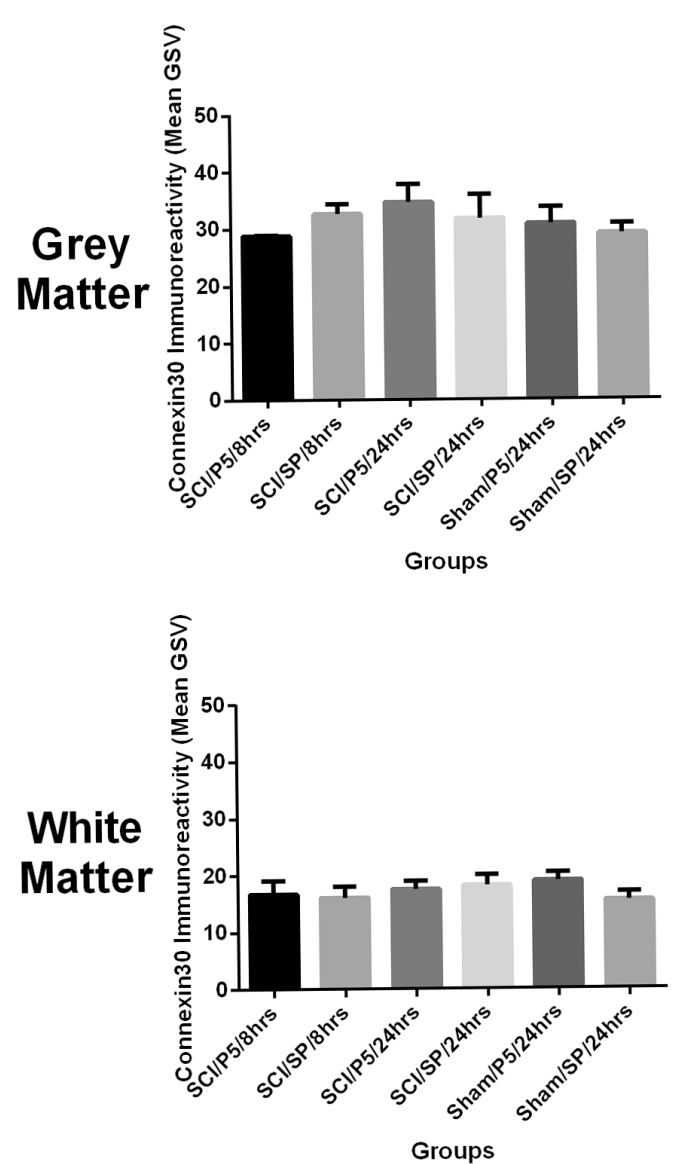

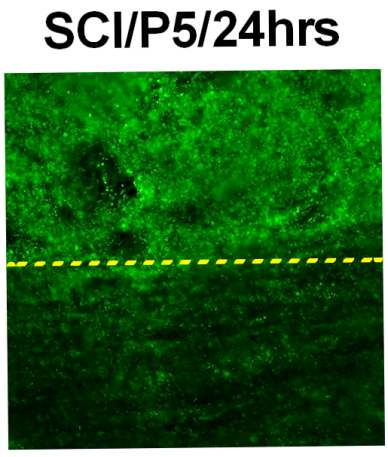

Sham/P5/24hrs

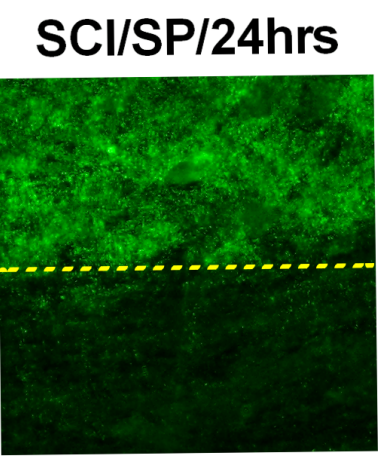

Sham/SP/24hrs

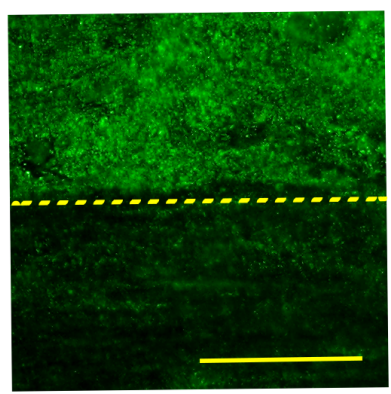

$3.5 \mathrm{~mm}$
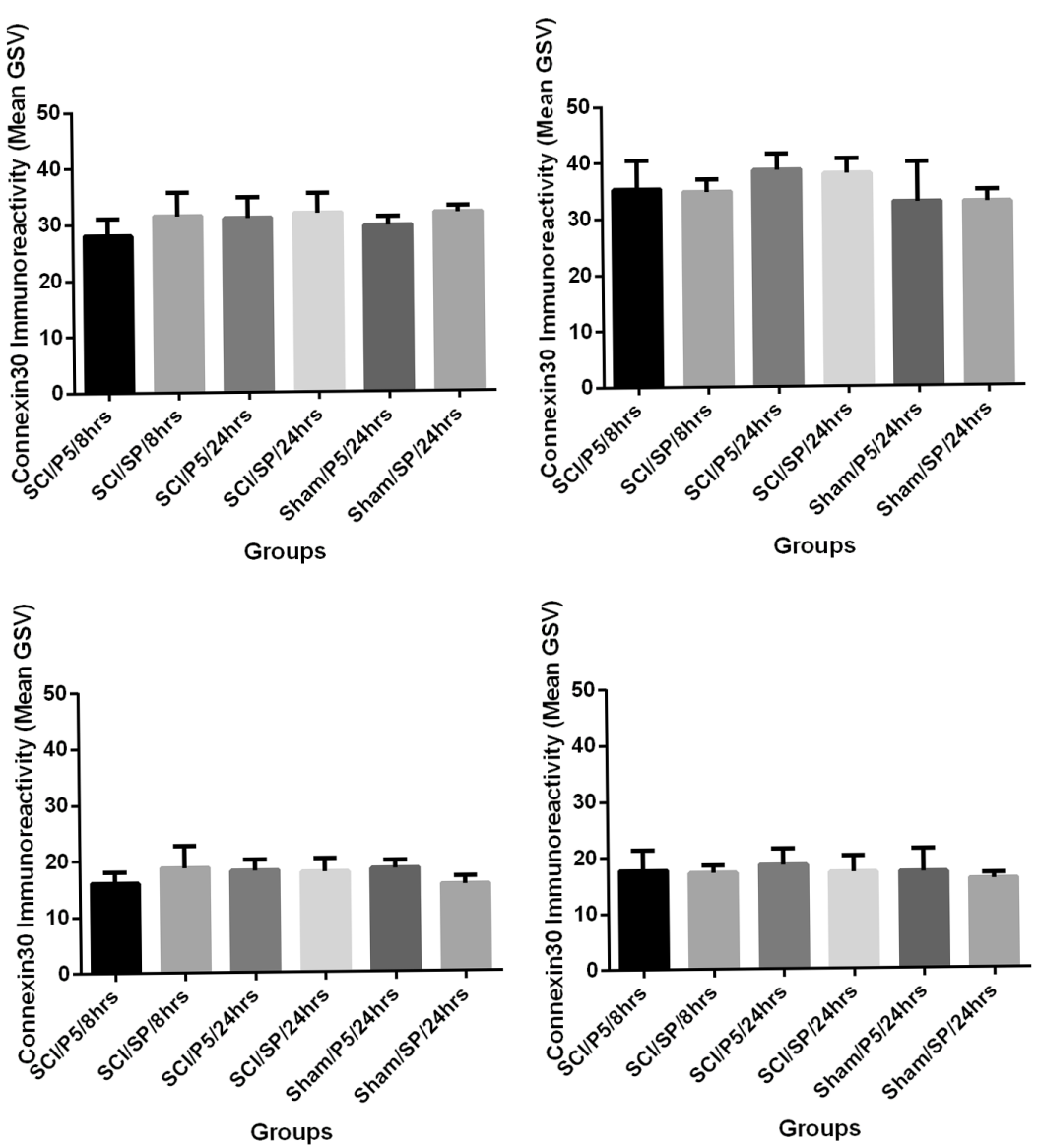


\section{Connexin36}

A
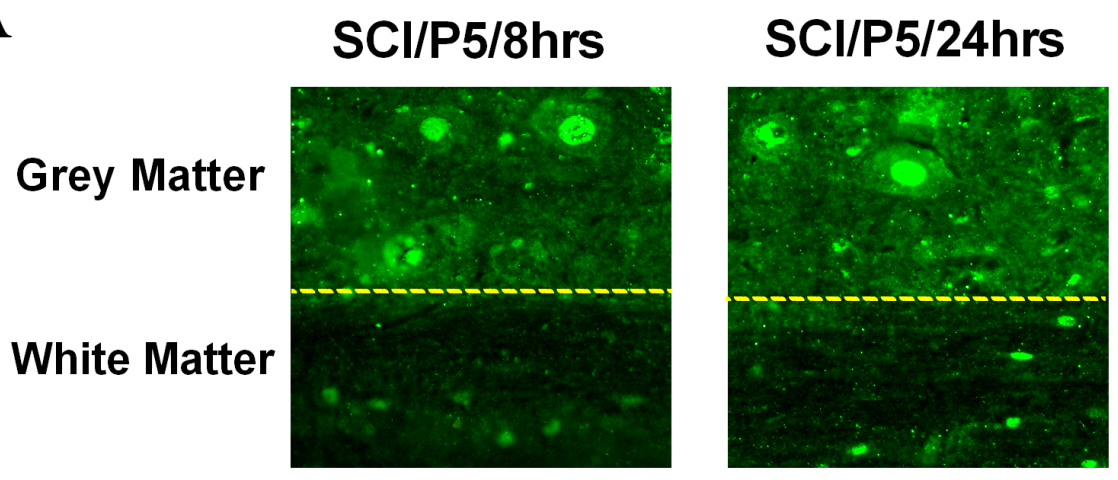

Sham/P5/24hrs
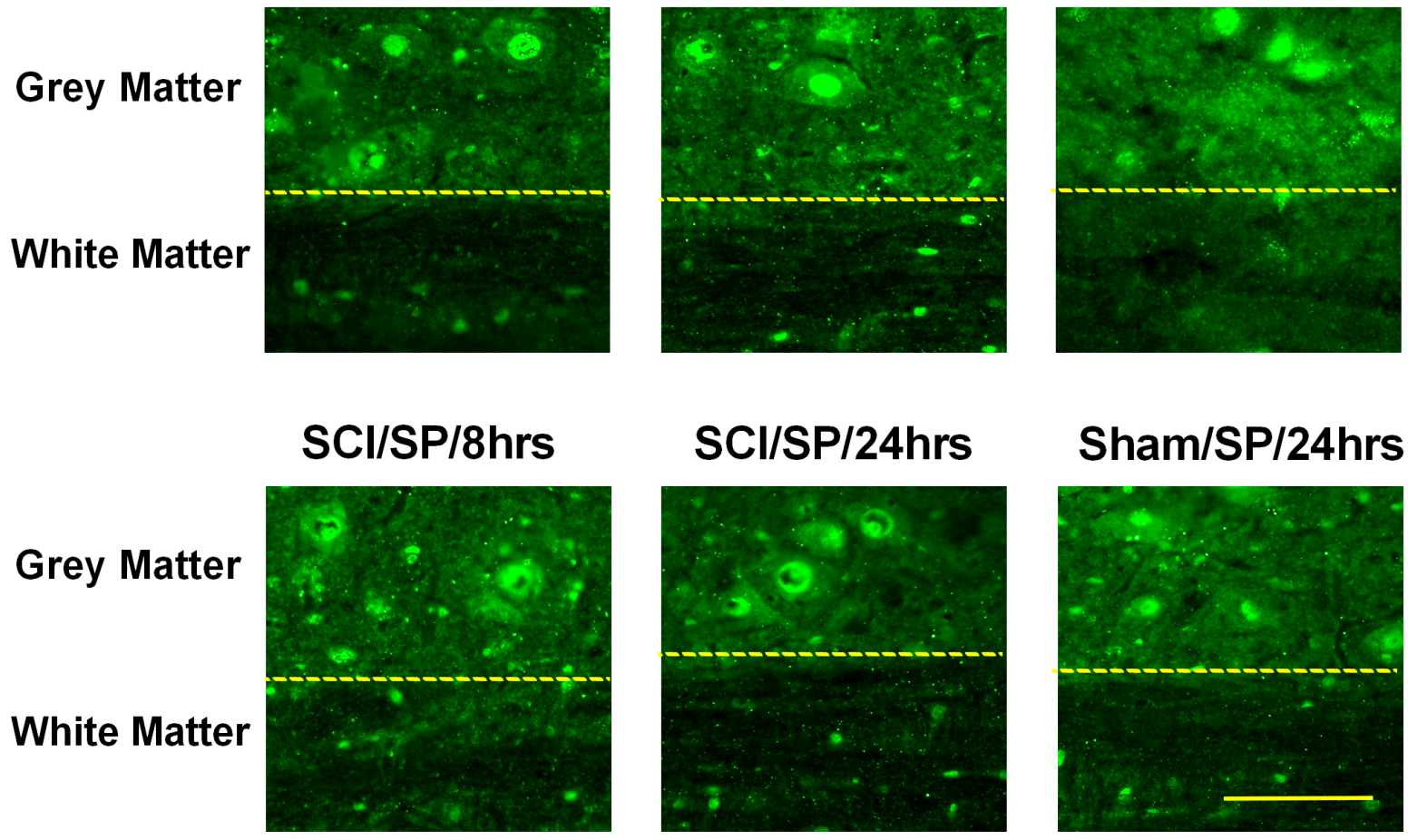

B

$7 \mathrm{~mm}$

$3.5 \mathrm{~mm}$

Sham/SP/24hrs
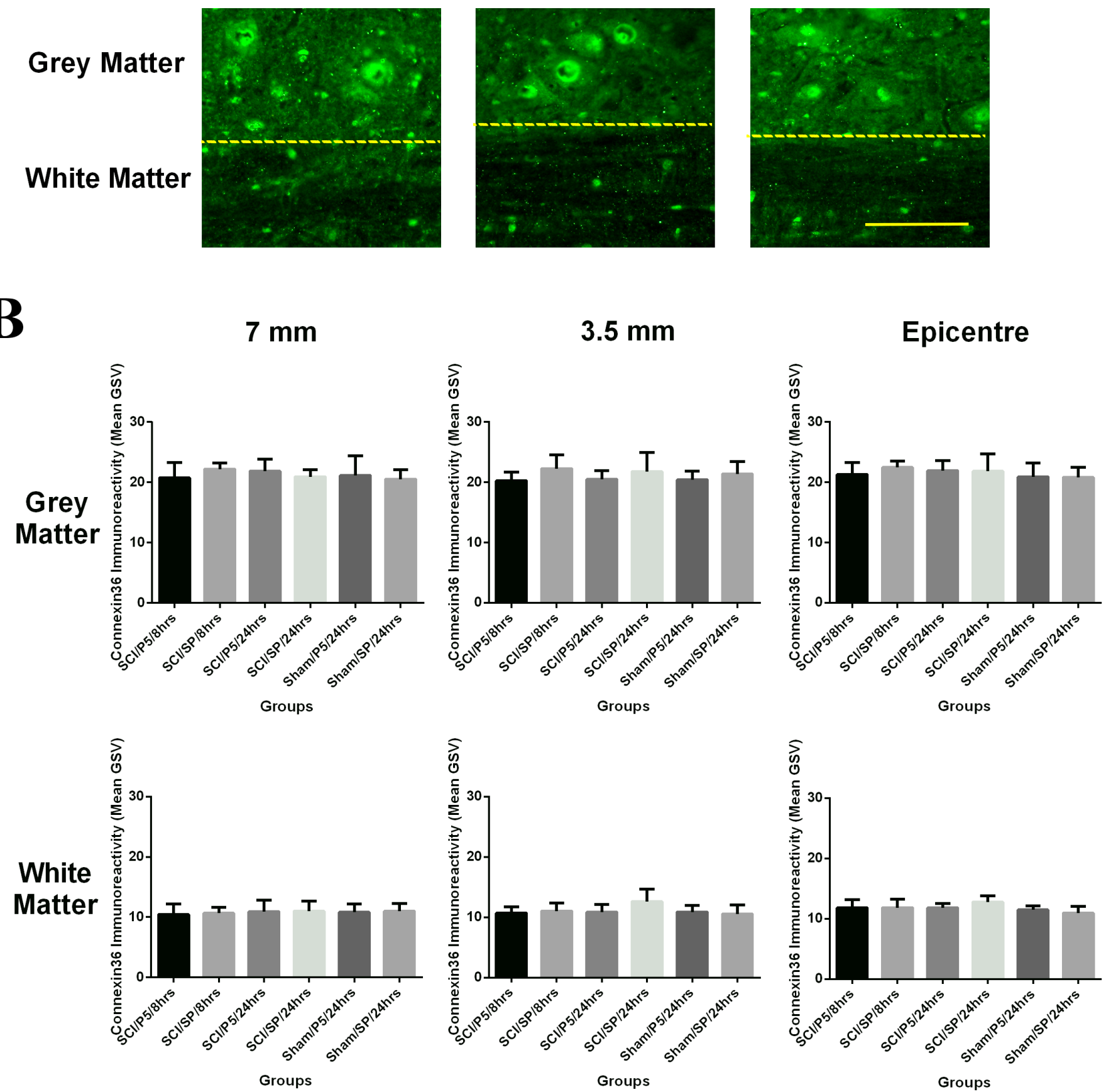


\section{Connexin47}

A
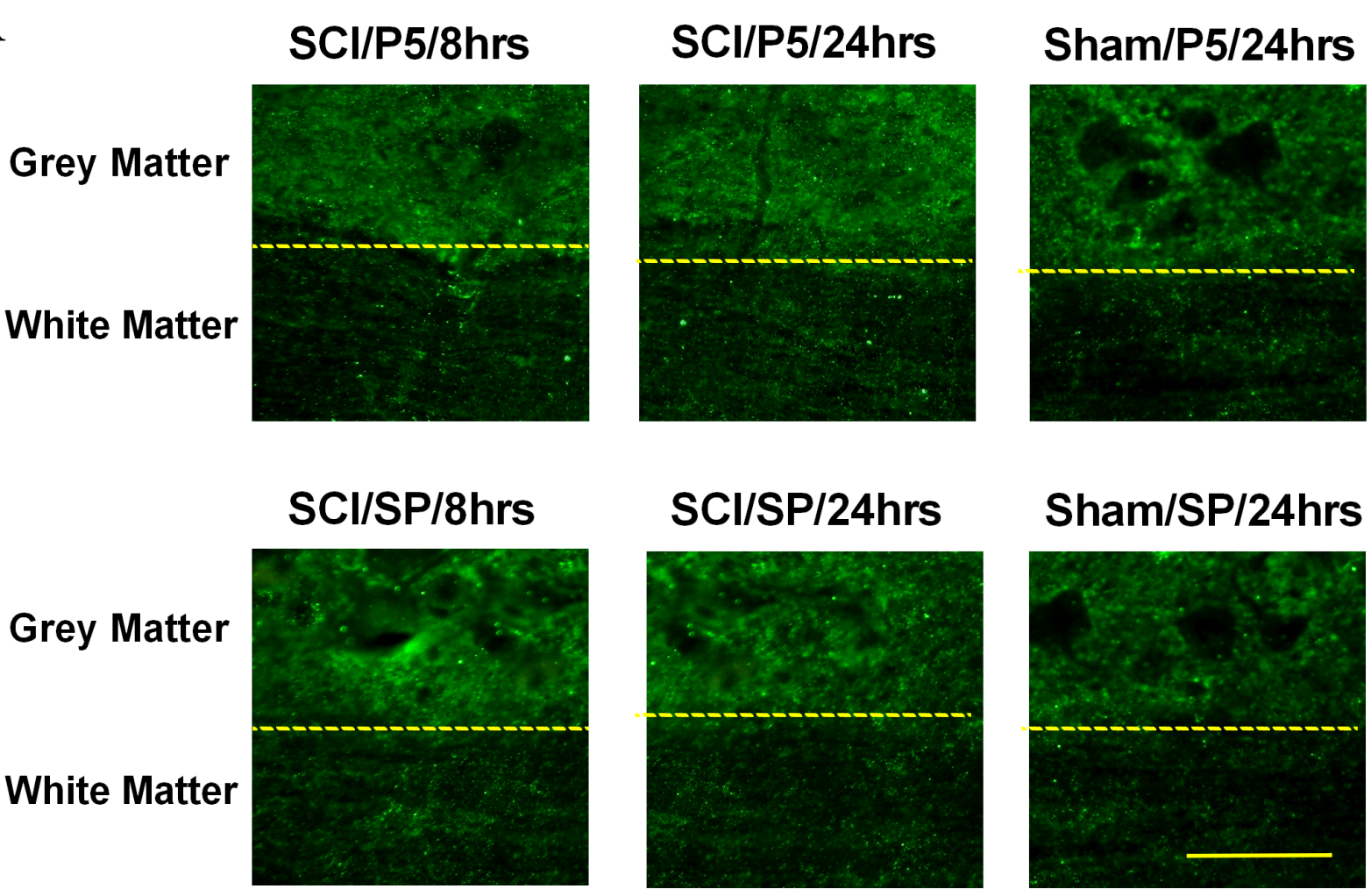

B

$7 \mathrm{~mm}$
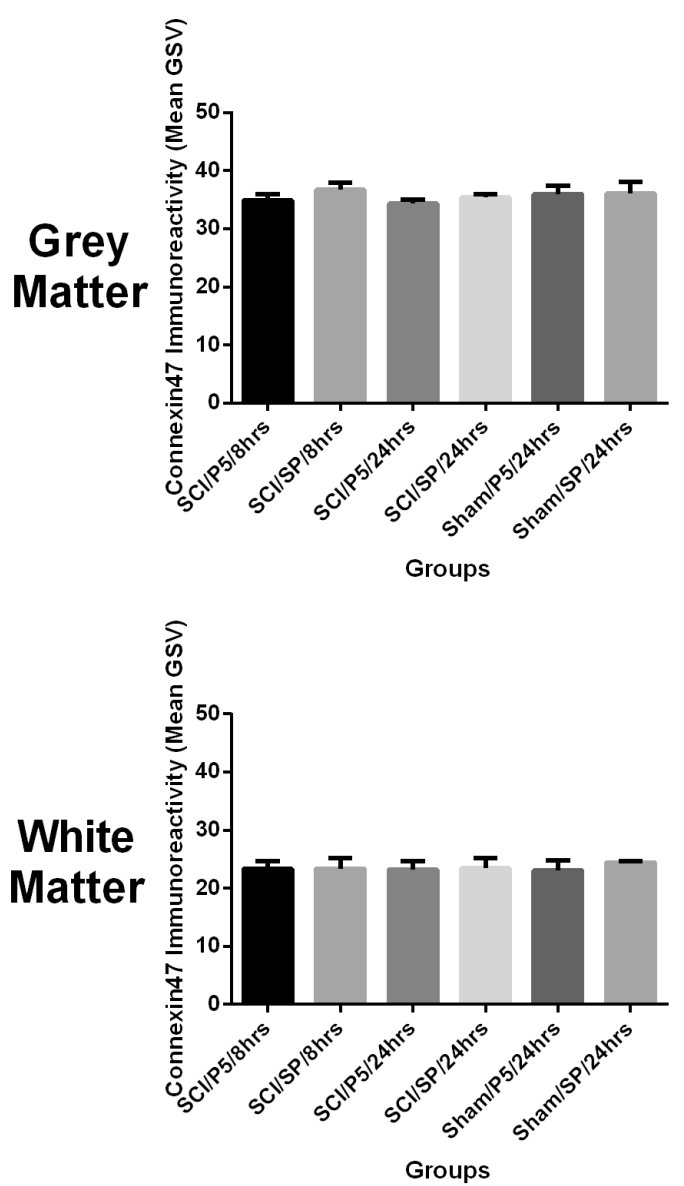

$3.5 \mathrm{~mm}$
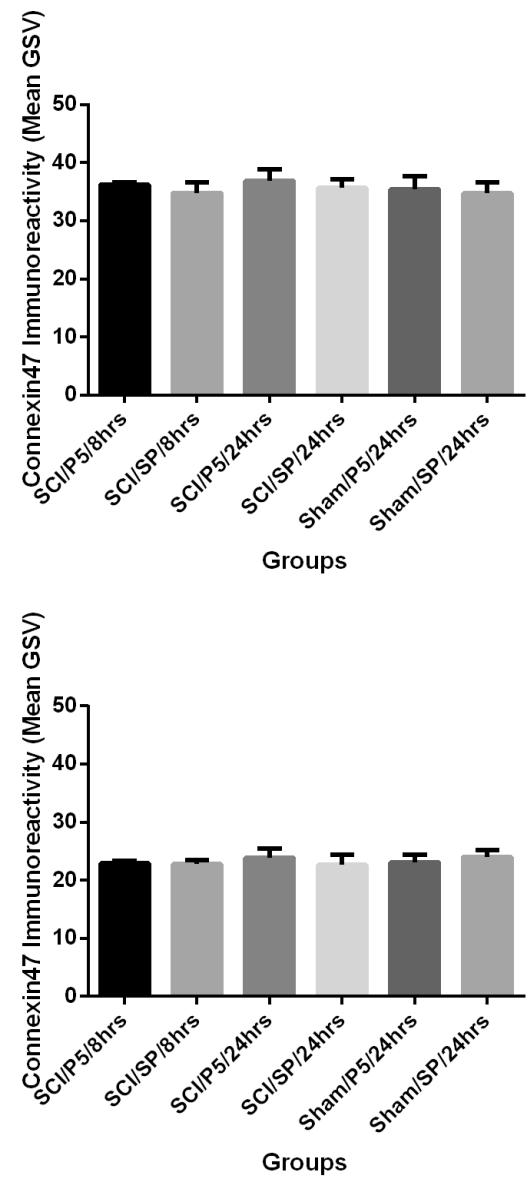

Epicentre
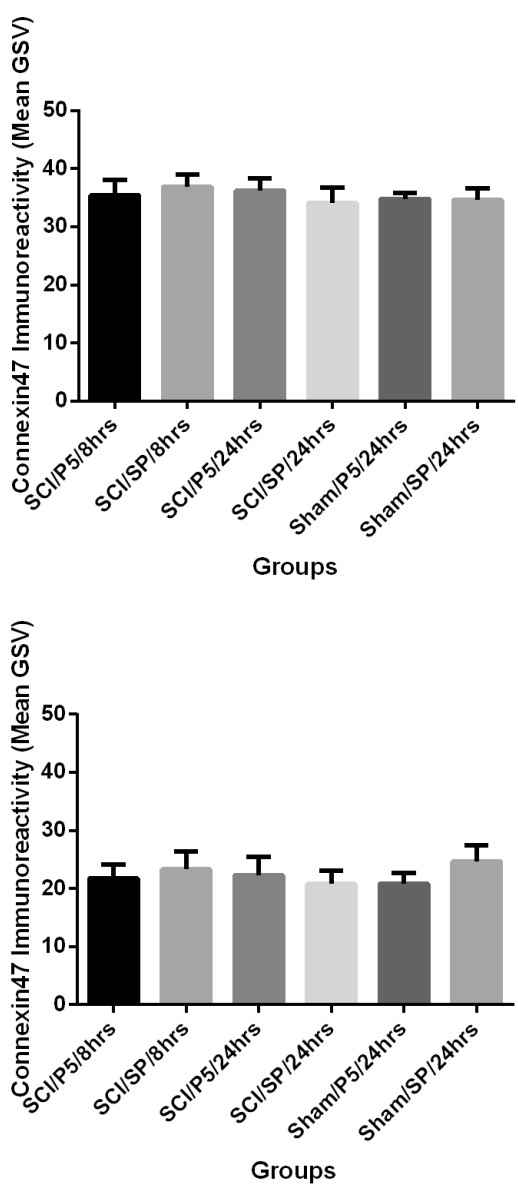